\title{
Memantine and Ketamine Differentially Alter NMDA Receptor Desensitization
}

\author{
ํำ Nathan G. Glasgow, ${ }^{1}$ Nadezhda V. Povysheva, ${ }^{1}$ Andrea M. Azofeifa, ${ }^{1}$ and ${ }^{\oplus}$ Jon W. Johnson ${ }^{1,2}$ \\ ${ }^{1}$ Department of Neuroscience and Center for Neuroscience and ${ }^{2}$ Department of Psychiatry, University of Pittsburgh, Pittsburgh, Pennsylvania 15260
}

Memantine and ketamine are clinically useful NMDA receptor (NMDAR) open channel blockers that inhibit NMDARs with similar potency and kinetics, but display vastly different clinical profiles. This discrepancy has been hypothesized to result from inhibition by memantine and ketamine of overlapping but distinct NMDAR subpopulations. For example, memantine but not ketamine may inhibit extrasynaptic NMDARs more effectively than synaptic NMDARs. However, the basis for preferential NMDAR inhibition depending on subcellular location has not been investigated systematically. We integrated recordings from heterologously expressed single NMDAR subtypes, kinetic modeling, and recordings of synaptically evoked NMDAR responses in acute brain slices to investigate mechanisms by which channel blockers may distinguish NMDAR subpopulations. We found that memantine and ketamine differentially alter NMDAR desensitization and that memantine stabilizes a $\mathrm{Ca}^{2+}$-dependent desensitized state. As a result, inhibition by memantine of GluN1/2A receptors in tsA201 cells and of native synaptic NMDARs in cortical pyramidal neurons from mice of either sex increased in conditions that enhanced intracellular $\mathrm{Ca}^{2+}$ accumulation. Therefore, differential inhibition by memantine and ketamine based on NMDAR location is likely to result from location dependence of the intensity and duration of NMDAR activation. Modulation of $\mathrm{Ca}^{2+}$-dependent NMDAR desensitization is an unexplored mechanism of inhibitory action with the potential to endow drugs with NMDAR selectivity that leads to superior clinical profiles. Our results suggest that designing compounds to target specific receptor states, rather than specific receptor types, may be a viable strategy for future drug development.

Key words: desensitization; extrasynaptic NMDA receptors; NMDA receptor subtype; open channel block; synaptic NMDA receptors

\section{Significance Statement}

Memantine and ketamine are NMDA receptor (NMDAR) channel-blocking drugs with divergent clinical effects. Understanding mechanistically their differential actions may advance our understanding of nervous system disorders and suggest strategies for the design of more effective drugs. Here, we show that memantine and ketamine have contrasting effects on NMDAR desensitization. Ketamine binding decreases occupancy of desensitized states of the GluN1/2B NMDAR subtype. In contrast, memantine binding increases occupancy of GluN1/2A and native NMDAR desensitized states entered after accumulation of intracellular $\mathrm{Ca}^{2+}$, a novel inhibitory mechanism. These properties may contribute to inhibition of distinct NMDAR subpopulations by memantine and ketamine and help to explain their differential clinical effects. Our results suggest stabilization of $\mathrm{Ca}^{2+}$-dependent desensitized states as a new strategy for pharmaceutical neuroprotection.

\section{Introduction}

NMDA receptors (NMDARs) are a subfamily of ionotropic glutamate receptors that exhibit unique biophysical properties in-

\footnotetext{
Received April 29, 2017; revised Aug. 7, 2017; accepted Aug. 30, 2017.

Author contributions: N.G.G., N.V.P., A.M.A., and J.W.J. designed research; N.G.G., N.V.P., and A.M.A. performed research; N.G.G., N.V.P., A.M.A., and J.W.J. analyzed data; N.G.G., N.V.P., and J.W.J. wrote the paper.

This work was supported by the National Institutes of Health (Grant R01 MH045817 to J.W.J. and Grants F31 MH105056, T32 NS073548, and T32 NS007433 to N.G.G.). We thank Christen Shiber, Lihua Ming, and James Buhrman for excellent technical assistance and Madeleine Wilcox and Anne Homan for constructive comments on the manuscript.

The authors declare no competing financial interests.

Correspondence should be addressed to Jon W. Johnson, Department of Neuroscience, University of Pittsburgh, A210 Langley Hall, Pittsburgh, PA 15260. E-mail: jjohnson@pitt.edu.
}

cluding high $\mathrm{Ca}^{2+}$ permeability and voltage-dependent block by $\mathrm{Mg}^{2+}$ (Paoletti et al., 2013; Glasgow et al., 2015). Synaptic NMDARs play a central role in essential physiological processes (Traynelis et al., 2010; Paoletti et al., 2013) and extrasynaptic NMDARs also contribute to normal neuronal physiology (Fellin et al., 2004; Herman and Jahr, 2007; Le Meur et al., 2007; Harris and Pettit, 2008; Povysheva and Johnson, 2012; Riebe et al., 2016). Aberrant activation of NMDARs is implicated in pathological processes including excitotoxicity (Paoletti et al., 2013; Parsons and Raymond, 2014). NMDAR subcellular localization

DOI:10.1523/JNEUROSCI.1173-17.2017

Copyright $\odot 2017$ the authors $\quad 0270-6474 / 17 / 379686-19 \$ 15.00 / 0$ 
has been proposed to underlie a dichotomy in the effects of NMDAR-mediated signaling, with synaptic NMDAR activation promoting cell survival, but extrasynaptic NMDAR activation promoting excitotoxicity (Hardingham and Bading, 2010; Parsons and Raymond, 2014). However, synaptic NMDAR activation clearly also plays a role in excitotoxicity (Papouin et al., 2012; Wroge et al., 2012; Zhou et al., 2013a; Zhou et al., 2013b).

The idea that different NMDAR subpopulations are involved in distinct processes also underlies one of several hypothesized explanations for the differential actions of two clinically relevant NMDAR open channel blockers, memantine and ketamine (Lipton, 2006; Parsons et al., 2007; Kotermanski et al., 2013; Abdallah et al., 2015; Johnson et al., 2015; Kavalali and Monteggia, 2015). Memantine is approved for treatment of Alzheimer's disease and shows promise in treatment of other nervous system disorders including Huntington's disease and ischemia (Lipton, 2006; Parsons et al., 2007; Kafi et al., 2014; Parsons and Raymond, 2014; Johnson et al., 2015). In contrast, ketamine has shown efficacy in the treatment of pain and as a fast-acting antidepressant (Persson, 2013; Abdallah et al., 2015; Kavalali and Monteggia, 2015). Ketamine (but not memantine) reproduces symptoms of schizophrenia and is a drug of abuse (Krystal et al., 2003; Corazza et al., 2013; Johnson et al., 2015). The divergent clinical profiles of memantine and ketamine could arise in part from the drugs inhibiting overlapping but distinct NMDAR subpopulations. Memantine has been hypothesized to provide neuroprotection through more potent inhibition of extrasynaptic than synaptic NMDARs (Zhao et al., 2006; Léveillé et al., 2008; Okamoto et al., 2009; Milnerwood et al., 2010; Xia et al., 2010; but see Wroge et al., 2012; Emnett et al., 2013; Zhou et al., 2013b). In contrast, most evidence does not suggest that ketamine distinguishes between synaptic and extrasynaptic NMDARs (Autry et al., 2011; Emnett et al., 2013; Nosyreva et al., 2013; Gideons et al., 2014; Miller et al., 2014). However, mechanisms by which memantine and ketamine inhibit distinct NMDAR subpopulations selectively have not been clearly established. Note that there are additional differences between memantine and ketamine that are likely to contribute to their differential clinical actions (for reviews, see Parsons et al., 2007; Beconi et al., 2011; Johnson et al., 2015), including binding of drugs or metabolites to non-NMDAR targets (Maskell et al., 2003; Lu et al., 2010; Zanos et al., 2016) and differences in pharmacokinetics resulting from, for example, differences in metabolism and $\mathrm{pK}_{\mathrm{a}}$ (Hesselink et al., 1999; Lord et al., 2013; but see Kotermanski et al., 2013).

To probe how memantine and ketamine could inhibit distinct NMDAR subpopulations, we investigated the dependence of memantine and ketamine inhibition on three characteristics that are likely to vary between synaptic and extrasynaptic NMDARs. The first characteristic is NMDAR subtype. In many neuronal subtypes, there is preferential inclusion of GluN2A subunits in synaptic NMDARs and of GluN2B subunits in extrasynaptic NMDARs (Tovar and Westbrook, 1999; Groc et al., 2006; Papouin et al., 2012), although both GluN2A and GluN2B subunits are expressed at both locations (Thomas et al., 2006b; Harris and Pettit, 2007; Petralia et al., 2010). The second characteristic is the glutamate concentration, which reaches much higher levels at synaptic than at extrasynaptic NMDARs. The final characteristic is duration of glutamate exposure. NMDAR exposure to glutamate is typically much briefer at synaptic than at extrasynaptic NMDARs.

\section{Materials and Methods}

Cell culture and transfection. Experiments were performed on the tsA201 cell line (The European Collection of Authenticated Cell Cultures, ECACC catalog \#96121229, RRID: CVCL_2737), which is a variant of the HEK 293 cell line. tsA201 cells were maintained as described previously (Glasgow and Johnson, 2014) in DMEM supplemented with 10\% fetal bovine serum and 1\% GlutaMAX (Thermo Fisher Scientific). Cells were plated at $1 \times 10^{5}$ cells/dish on $15 \mathrm{~mm}$ glass coverslips in $35 \mathrm{~mm}$ Petri dishes. Coverslips were untreated for experiments using lifted cells and treated with poly D-lysine $(0.1 \mathrm{mg} / \mathrm{ml})$ and rat-tail collagen $(0.1 \mathrm{mg} / \mathrm{ml}$; BD Biosciences) for experiments using unlifted cells. Twelve to $24 \mathrm{~h}$ after plating, the cells were transiently cotransfected using FuGENE 6 Transfection Reagent (Promega) with mammalian expression plasmids that contained cDNAs encoding enhanced green fluorescent protein (EGFP in pRK7) for identification of transfected cells, the rat GluN1-1a subunit (referred to here as GluN1; GenBank X63255 in pcDNA3.1) and either the rat GluN2A subunit (GenBank M91561 in pcDNA1) or the rat GluN2B subunit (GenBank M91562 in pcDNA1). For some experiments, we used cells transfected with the GluN1 plasmid and a plasmid containing an EGFP:pIRES:GluN2A construct, which was a kind gift from Dr. Kasper Hansen. Briefly, this plasmid was constructed by inserting EGFP in pIRES (Clontech) under transcriptional control of the CMV promoter and inserting the open reading frame of rat GluN2A (GenBank D13211) after the IRES sequence. cDNA ratios of 1 EGFP: 1 GluN1: 1 GluN2A; 1 GluN1: 1 EGFP:pIRES:GluN2A; or 1 EGFP: 1 GluN1: 3 GluN2B were used. Immediately after transfection, the culture medium was supplemented with the competitive NMDAR antagonists D,L-2-amino-5-phosphonopentanoate $(200 \mu \mathrm{M})$ and 7-chlorokynurenic acid $(200 \mu \mathrm{M})$ to prevent NMDAR-mediated cell death.

Patch-clamp recordings from tsA201 cells. Whole-cell voltage-clamp recordings were performed on transfected tsA201 cells 12-48 h after transfection. Unless otherwise indicated, the normal extracellular solution contained the following (in mM): $140 \mathrm{NaCl}, 2.8 \mathrm{KCl}, 1 \mathrm{CaCl}_{2}, 10 \mathrm{HEPES}$, 0.01 EDTA, and 0.1 glycine, balanced to $\mathrm{pH} 7.2 \pm 0.05$ with $\mathrm{NaOH}$ and osmolality raised to $290 \pm 10 \mathrm{mOsm}$ with sucrose. Pipettes were pulled from borosilicate capillary tubing (Sutter Instruments) to a resistance of 2-5 M $\Omega$ on a Flaming Brown P-97 electrode puller (Sutter Instruments) and fire polished. Unless otherwise indicated, the intracellular pipette solution contained the following (in $\mathrm{mM}$ ): $130 \mathrm{CsCl}, 10$ HEPES, 10 BAPTA, and $4 \mathrm{MgATP}$ balanced to $\mathrm{pH} 7.2 \pm 0.05$ with $\mathrm{CsOH}$; solution osmolality was $280 \pm 10 \mathrm{mOsm}$. BAPTA was chosen as the intracellular $\mathrm{Ca}^{2+}$ buffer to reduce NMDAR current rundown during long experiments (Rosenmund and Westbrook, 1993). MgATP was also added to the intracellular pipette solution to reduce NMDAR current rundown, although some experiments measuring inhibition by memantine and ketamine were performed without addition of MgATP. We did not observe an effect of MgATP on inhibition and therefore data were pooled. Solutions were delivered with an in-house fabricated fast perfusion system described below. In Figure 7, the extracellular and intracellular solutions used for recordings from tsA201 cells were as follows: for "high$\mathrm{Ca}^{2+”}$ conditions, normal extracellular solution was used, but in the intracellular solution, $1 \mathrm{~mm}$ EGTA $\left(\mathrm{EGTA}_{\mathrm{i}}\right)$ replaced $10 \mathrm{~mm} \mathrm{BAPTA}_{\mathrm{i}}$; for "low- $\mathrm{Ca}^{2+}$ " conditions, in the extracellular solution, $0.1 \mathrm{mM} \mathrm{CaCl}_{2}$ replaced $1 \mathrm{mM} \mathrm{CaCl}_{2}$ and normal intracellular solution was used.

Whole-cell currents were recorded using an Axopatch 200B patchclamp amplifier (Molecular Devices), low-pass filtered at $5 \mathrm{kHz}$, and sampled at $20 \mathrm{kHz}$ using a Digidata 1440 digitizer and Clampex 10.3 software (Molecular Devices). Series resistance was compensated 85$90 \%$ with the prediction and correction circuitry in all experiments. Experiments in which series resistance exceeded $20 \mathrm{M} \Omega$ were excluded from analysis. A liquid junction potential of $-6 \mathrm{mV}$ between the pipette solution and extracellular solution was corrected in all experiments.

Patch-clamp recordings from prefrontal cortex (PFC) pyramidal neurons. Experiments were performed on PFC slices from 5- to 8-month-old wild-type mixed-background C57BL/6J, BALB/cJ mice of either sex. All animal procedures were conducted in accordance with the National Institutes of Health's Guide for the Care and Use of Laboratory Animals and approved by the University of Pittsburgh Institutional An- 
imal Care and Use Committee. Mice were deeply anesthetized with chloral hydrate and decapitated. The brain was quickly removed and immersed in ice-cold preoxygenated artificial CSF (ACSF). A tissue block containing the prelimbic cortex was excised for slicing. Coronal slices (350 $\mu \mathrm{m}$ thick) were cut with a vibratome (VT1000S; Leica). Slices were incubated at $37^{\circ} \mathrm{C}$ for $0.5-1 \mathrm{~h}$ and further stored at room temperature until they were transferred to a recording chamber perfused with ACSF with a $95 \% \mathrm{O}_{2} / 5 \% \mathrm{CO}_{2}$ gas mixture at $31-32^{\circ} \mathrm{C}$. ACSF used for slicing and incubation contained the following (in $\mathrm{mM}$ ): $126 \mathrm{NaCl}, 2.5 \mathrm{KCl}, 1.25$ $\mathrm{NaH}_{2} \mathrm{PO}_{4}, 1 \mathrm{MgSO}_{4}, 2 \mathrm{CaCl}_{2}, 24 \mathrm{NaHCO}_{3}$, and $10-20$ glucose at $\mathrm{pH}$ 7.25-7.3. ACSF used for recordings contained the following (in $\mathrm{mM}$ ): for high-Ca ${ }^{2+}$ conditions, $126 \mathrm{NaCl}, 2.5 \mathrm{KCl}, 1.25 \mathrm{NaH}_{2} \mathrm{PO}_{4}, 0.5 \mathrm{MgSO}_{4}, 2$ $\mathrm{CaCl}_{2}, 24 \mathrm{NaHCO}_{3}, 10-20$ glucose, and 0.01 glycine, with $\mathrm{pH}$ 7.25-7.3; for low-Ca ${ }^{2+}$ conditions, $126 \mathrm{NaCl}, 2.5 \mathrm{KCl}, 1.25 \mathrm{NaH}_{2} \mathrm{PO}_{4}, 0.5 \mathrm{MgSO}_{4}$, $1 \mathrm{CaCl}_{2}, 24 \mathrm{NaHCO}_{3}, 10-20$ glucose, and 0.01 glycine at $\mathrm{pH} 7.25-7.3$. To isolate NMDAR-mediated postsynaptic currents (NMDAR-EPSCs) from other ionotropic currents, we used gabazine (10 $\mu \mathrm{M}$; Ascent Scientific) and 2,3-dihydroxy-6-nitro-7-sulfamoylbenzo(F) quinoxaline (NBQX; $20 \mu \mathrm{M}$; Ascent Scientific). Pipettes were pulled from borosilicate capillary tubing to a resistance of 5-10 $\mathrm{M} \Omega$ on a Flaming Brown P-97 electrode puller. Patch electrodes were filled with an intracellular pipette solution containing the following (in mM:) for high- $\mathrm{Ca}^{2+}$ conditions, $115 \mathrm{Cs}-$ gluconate, $2 \mathrm{MgCl}_{2}, 10 \mathrm{NaCl}, 10 \mathrm{HEPES}, 10$ phosphocreatine, $4 \mathrm{MgATP}$, $0.3 \mathrm{GTP}$, balanced to $\mathrm{pH} 7.25 \pm 0.05$ with $\mathrm{CsOH}$; for low- $\mathrm{Ca}^{2+}$ conditions, 105 Cs-gluconate, $2 \mathrm{MgCl}_{2}, 10 \mathrm{NaCl}, 10 \mathrm{HEPES}, 10$ phosphocreatine, 4 MgATP, 0.3 GTP, and 10 BAPTA, balanced to $\mathrm{pH} 7.25 \pm 0.05$ with $\mathrm{CsOH}$.

Whole-cell recordings were performed from layer II/III pyramidal neurons visualized by IR-DIC videomicroscopy using an Axioskop microscope (Carl Zeiss) with a $60 \times$ water-immersion objective and a digital video camera (CoolSnap; Photometrics). Pyramidal neurons were identified by their apical dendrites and triangular somata. Whole-cell currents were recorded using a Multi-Clamp 700A amplifier (Molecular Devices), low-pass filtered at $2 \mathrm{kHz}$, and sampled at $10 \mathrm{kHz}$ using a Digidata 1440 digitizer and Clampex 10.2 software (Molecular Devices). Series resistance compensation was not used. Access resistance typically was 10-20 M $\Omega$ and remained relatively stable during experiments ( $\leq 30 \%$ increase) for the cells included in the analysis. Membrane potential was corrected for the liquid junction potential of $-13 \mathrm{mV}$.

NMDAR-EPSCs were evoked by extracellular stimulation at a holding potential of $-65 \mathrm{mV}$. Bipolar electrodes made from theta glass were placed on the border of white matter and layer VI near the patch-clamped layer II/III pyramidal neuron. An A360 stimulus isolator (World Precision Instruments) was used to generate current stimuli that were triggered digitally with the Clampex software. NMDAR-EPSCs were evoked by applying trains of 10 stimuli at $25 \mathrm{~Hz}$ ( $40 \mathrm{~ms}$ interstimulus intervals) with an intertrain interval of $10 \mathrm{~s}$.

Concentration-inhibition relations. Concentration-inhibition relations for memantine and ketamine during NMDAR activation by $1 \mathrm{~mm}$ or $0.3 \mu \mathrm{M}$ glutamate were determined using the following protocol. Glutamate was applied for 10-20 s until current reached steady state and then glutamate with $0.1,1,10$, or $100 \mu \mathrm{M}$ drug was applied for $10-40 \mathrm{~s}$ until a new steady-state current level was reached. Glutamate in the absence of drug was then reapplied for 20-60 s to allow recovery from inhibition. The time needed to reach a steady level of inhibition and to allow recovery from inhibition depended strongly on the glutamate concentration, as expected for open channel blockers. Concentration-inhibition relations for memantine in high- and low- $\mathrm{Ca}^{2+}$ conditions were measured using the protocol shown in Figure 7C. Experiments in which recovery from inhibition did not reach $90 \%$ of steady-state current preceding drug application were excluded from analysis.

Fast perfusion system. An in-house-fabricated fast perfusion system similar to a system described previously (Glasgow and Johnson, 2014) was used to deliver solutions to cells. Solutions were delivered through 10 round plastic barrels ( $0.5 \mathrm{~mm}$ interior diameter; Phelps Dodge) for recordings from unlifted cells and through 3 square glass barrels $(0.6 \mathrm{~mm}$ interior diameter; Warner Instruments) for recordings from lifted cells. Barrel orifices were positioned $\sim 0.25 \mathrm{~mm}$ from the cells with barrels at an $\sim 30^{\circ}$ angle relative to the coverslip on which cells were cultured.
Barrels were attached via polyethylene tubing to solution reservoirs. Solution flow rate was controlled by adjusting the height of the solution reservoirs and was typically $\sim 2 \mathrm{ml} / \mathrm{min}$ for recordings from unlifted cells and $\sim 1 \mathrm{ml} / \mathrm{min}$ for recordings from lifted cells. Solution changes were achieved by changing the barrel position with a voice-coil-driven linear stage and controller (Equipment Solutions); position command was provided by a custom program similar to one described previously (Blanpied et al., 1997).

Synaptic-like glutamate applications to lifted cells were achieved by quickly changing barrel position from barrel 1 to barrel 3 and from barrel 3 to barrel 1, briefly sweeping by the glutamate-containing barrel 2, as depicted in Figure $2 \mathrm{~A}$. We assessed the solution exchange time course during movements from barrel 1 to barrel 3 and barrel 3 to barrel 1 by measuring the relaxation of an open pipette junction potential when barrels 1 and 3 contained normal extracellular solution, whereas barrel 2 contained extracellular solution diluted $\sim 50 \%$. Solution exchange during a movement from barrel 1 to barrel 3 and from barrel 3 to barrel 1 had a $10-90 \%$ rise time of $0.18 \pm 0.05 \mathrm{~ms}$ (mean $\pm \mathrm{SD}$; see Fig. $2 A, B$ ). The duration of synaptic-like glutamate applications was determined after each experiment by diluting the solution in barrel 2 by $\sim 50 \%$, applying pressure to clear the cell from the tip of the recording pipette, and measuring the duration of the junction current change recorded by the open pipette. Synaptic-like glutamate applications had a mean half-width of $2.54 \pm 1.37 \mathrm{~ms}$ (mean $\pm \mathrm{SD}$ ). Experiments in which applications were $<1 \mathrm{~ms}$ or $>6 \mathrm{~ms}$ or in which open pipette tip junction currents displayed more than one peak were excluded from analysis. For experiments that did not involve synaptic-like glutamate applications, we determined the time course of solution exchange around lifted and unlifted whole cells by recording current relaxations after movements from barrel 1 to barrel 2; barrel 1 contained normal extracellular solution and $1 \mathrm{~mm}$ glutamate and barrel 2 contained extracellular solution with $50 \% \mathrm{NaCl}$ and $1 \mathrm{~mm}$ glutamate. Solution exchange around a lifted whole cell had a $10-90 \%$ rise time of $3.37 \pm 0.65 \mathrm{~ms}$ (mean $\pm \mathrm{SD}$ ) and was well fit by a single exponential with a time constant of $2.02 \pm 0.35 \mathrm{~ms}$ (mean \pm SD). Solution exchange around an unlifted whole cell had a $10-90 \%$ rise time of $150 \pm 35 \mathrm{~ms}$ (mean $\pm \mathrm{SD}$ ) and was well fit by a single exponential with a time constant of $27.4 \pm 6.6 \mathrm{~ms}$ (mean $\pm \mathrm{SD}$ ).

We used the following protocol to measure inhibition of peak NMDAR currents in response to synaptic-like glutamate applications (see Figs. $3 A-D, 7 B$ ). We delivered 10 synaptic-like glutamate applications in the absence of drug to determine the control peak current amplitude (control; 10 applications). Then, we delivered synaptic-like glutamate applications in the continuous presence of memantine or ketamine until reaching a steady level of inhibition (drug; 20 applications with memantine for GluN1/2A and GluN1/2B receptors, 60 applications with ketamine for GluN1/2A receptors, and 40 applications with ketamine for GluN1/2B receptors). Finally, we delivered synaptic-like glutamate applications in the absence of drug to allow recovery from inhibition (recovery; 20 applications for memantine and 40 applications for ketamine).

Kinetic modeling. All model-based current simulations and optimization of parameters (rate constants) based on fitting of models to data were performed in SCoP 3.52 (Simulation Resources). SCoP numerically solves the differential equations describing modeled kinetic schemes to determine the time-dependent occupancy of each state in response to stimuli such as agonist or drug application. Parameter optimization was achieved by minimizing the sum of squared differences between data point values and simulated current values (sum of squared errors). Currents were calculated as $I_{\mathrm{NMDA}}=N P_{\text {open }} \gamma\left(V_{\mathrm{m}}-V_{\text {rev }}\right)$, where $N$ is the number of receptors, $P_{\text {open }}$ is the probability of a receptor being in the open state, $\mathrm{RA}_{2}^{*}$ (see Figs. $4 A, 5 A$ ), $\gamma$ is the single-channel conductance (set to $50 \mathrm{pS}), V_{\mathrm{m}}$ is the membrane voltage $(-65 \mathrm{mV})$, and $V_{\text {rev }}$ is the reversal potential (set to $0 \mathrm{mV}$ ). $N$ was an arbitrary scaling factor because the model was fit to normalized currents. The models used here were adapted from previously published models (model 1 was from Chen et al., 2001, see Fig. 4A; model 2 was from Erreger et al., 2005, see Fig. 5A). Although we took care to choose models developed under similar experimental conditions (NMDAR subtype, cell type, solution $\mathrm{pH}$, and extracellular $\mathrm{Ca}^{2+}$ concentration), conditions were not identical, which lead 
to differences between our experimental recordings and current simulations from unmodified models. Therefore, all unblocked arm rates of models 1 and 2 except agonist binding and unbinding rates $\left(k_{\mathrm{a}+}\right.$ and $k_{\mathrm{a}-}$ ), which were unchanged from previously published models (Chen et al., 2001; Erreger et al., 2005), and $N$ first were optimized. Optimization of unblocked arm desensitization and gating rates and of $N$ was performed by fitting model 1 or model 2 to experimental recordings in the absence of drug. These experimental recordings were averages from 3 cells after normalization to peak current during a prolonged application of $1 \mathrm{~mm}$ glutamate; averages were used to account for differences between cells in desensitization and gating kinetics. Optimization of model 2 blocked arm rates was performed with experimental recordings averaged from the same three cells including during memantine application. Substantial differences in recording conditions between this study and studies that presented alternative carefully validated kinetic models related to model 2, but with different schemes (Schorge et al., 2005; Auerbach and Zhou, 2005; Kussius et al., 2009), prevented successful fits of alternative models to our control data. Therefore, kinetic examination was limited to models 1 and 2 presented here.

Model 1 unblocked arm rates were as follows: $k_{\mathrm{a}+}, 5 \mu \mathrm{M}^{-1} \mathrm{~s}^{-1} ; k_{\mathrm{a}-}$, $25 \mathrm{~s}^{-1} ; k_{1+}, 71 \mathrm{~s}^{-1} ; k_{1-}, 305 \mathrm{~s}^{-1} ; k_{\mathrm{d} 1+}, 6.9 \mathrm{~s}^{-1} ; k_{\mathrm{d} 1-}, 0.43 \mathrm{~s}^{-1}$. For models 1 and 2, we fixed memantine $k_{\text {on }}$ at $30 \mu \mathrm{M}^{-1} \mathrm{~s}^{-1}$ based on estimates made using our unpublished single-channel recordings, which is close to values of forward rates for other NMDAR open channel blockers (Jahr, 1992; Blanpied et al., 2005). The starting value in simulations and fits for memantine $k_{\text {off }}$ was $30 \mathrm{~s}^{-1}$ so that the initial $K_{\mathrm{d}}\left(k_{\text {off }} / k_{\text {on }}\right)$ was $1 \mu \mathrm{M}$. When individual rates in model 1 were modified 5-fold, memantine $k_{\text {off }}$ was adjusted to maintain the memantine $\mathrm{IC}_{50}$ for inhibition of long glutamate applications at $\sim 1 \mu \mathrm{M}$ (see Table 3 ). As described in Results, memantine $k_{\text {off }}$ was allowed to vary during fits used to optimize blocked arm rate constants of model 2.

Data analysis. Data were analyzed with Clampfit 10.3 (Molecular Devices), Prism 7 (GraphPad), or Origin 7.0 (OriginLab) software. Concentration-inhibition relations were plotted by calculating the ratio $I_{\text {drug }} / I_{\text {control }}$ at each drug concentration, where $I_{\text {drug }}$ is the mean current during $3 \mathrm{~s}$ of steady-state current in the presence of drug and $I_{\text {control }}$ is the mean current during $3 \mathrm{~s}$ of steady-state current before drug application and $3 \mathrm{~s}$ of steady-state current after recovery from drug inhibition. Ratios were then used to determine the $\mathrm{IC}_{50}$ value by a nonlinear least-squares fit of the equation $\left.\left.I_{\text {drug }} / I_{\text {control }}=1 /\left(1+([\mathrm{drug}]) / \mathrm{IC}_{50}\right)\right) \wedge n_{\mathrm{H}}\right)$, where $n_{\mathrm{H}}$ is the Hill coefficient. IC $\mathrm{C}_{50}$ and $n_{\mathrm{H}}$ were the free parameters during fits and were determined for each cell. $\mathrm{IC}_{50}$ values are presented as mean \pm SEM. For display of concentration-inhibition curves in figures, the average value of $I_{\text {drug }} / I_{\text {control }}$ was plotted at each drug concentration and overlaid with a fit to the plotted data.

Fits to data using single and double exponential functions were used to measure the rate of solution exchange, NMDAR deactivation time course (see Table 2), and time course of recovery from desensitization (see Figs. $6,7)$. NMDAR deactivation time course was always best fit by a double exponential function, whereas recovery from desensitization was sometimes equally well fit by a single exponential function. For comparison with single exponential time constants $(\tau)$, a weighted time constant $\left(\tau_{\mathrm{w}}\right)$ was calculated for double exponential fits by the following equation: $\tau_{\mathrm{w}}=\left(\tau_{\text {fast }} * A_{\text {fast }}+\tau_{\text {slow }} * A_{\text {slow }}\right) /\left(A_{\text {fast }}+A_{\text {slow }}\right)$, where the faster component had time constant $\tau_{\text {fast }}$ and amplitude $A_{\text {fast }}$ and the slower component has the time constant $\tau_{\text {slow }}$ and the amplitude $A_{\text {slow }}$.

Peak current $\left(I_{\text {peak }}\right)$ after synaptic-like glutamate applications was determined by measuring the mean current during a 3 ms window centered on the time when maximal current value was observed. Steady inhibition $\left(I_{\text {drug }} / I_{\text {control }}\right)$ of synaptic-like glutamate applications was measured as the mean $I_{\text {peak }}$ in response to the last five synaptic-like glutamate applications in the presence of drug $\left(I_{\text {drug }}\right)$, divided by the mean $I_{\text {peak }}$ in response to the first 10 control synaptic-like glutamate applications and the last 10 synaptic-like glutamate applications after recovery from inhibition $\left(I_{\text {control }}\right) . I_{\text {drug }} / I_{\text {control }}$ during long glutamate applications was measured as described above for concentration-inhibition relations. Cells were excluded from analysis if peak or steady-state currents did not display recovery from inhibition of at least $90 \%$ of the current preceding drug application. For presentation of group data, we calculated normal- ized $I_{\text {peak }}$ by dividing the $I_{\text {peak }}$ in response to each synaptic-like glutamate application by the mean $I_{\text {peak }}$ of the first 10 control synaptic-like glutamate applications.

To determine the time course of recovery from desensitization, $I_{\text {peak }}$ in response to long glutamate applications was measured as the mean current during a $30 \mathrm{~ms}$ window that started $5 \mathrm{~ms}$ before the time of peak current (see Figs. 6, 7). Normalized $I_{\text {peak }}$ was calculated by dividing each $I_{\text {peak }}$ value by the $I_{\text {peak }}$ measured after the longest interapplication interval $(200 \mathrm{~s})$, which was used to estimate $I_{\text {peak }}$ after full recovery from desensitization. Cells were excluded from analysis if any normalized $I_{\text {peak }}$ value was $>1.2$ because these cells likely experienced unacceptable NMDAR current rundown or changes of cell properties.

To quantify evoked NMDAR-EPSC amplitudes in PFC pyramidal neurons, we averaged current responses to $10-15$ consecutive stimulus trains and measured the peak negative current of the 10th NMDAREPSC. Current amplitude was measured relative to baseline current (current immediately before the visible onset of responses). Control current $\left(I_{\text {control }}\right)$ was measured from trains that preceded memantine application. Current in memantine $\left(I_{\mathrm{drug}}\right)$ was measured from trains recorded after $10 \mathrm{~min}$ of memantine application, after NMDAR-EPSCs had reached a steady level of inhibition.

Paired-pulse ratio (PPR) of NMDAR-EPSCs in PFC pyramidal neurons was estimated from the averaged current responses to the stimulus trains also used to quantify NMDAR-EPSC amplitudes. PPR was calculated as the peak negative current of the second response in 10-stimulus trains divided by the peak negative current of the first response. Current amplitudes were measured relative to baseline current (current immediately before the visible onset of responses) for the first response and relative to current at the end of the first response ( $1 \mathrm{~ms}$ before the second stimulus) for the second response.

Error is presented in the figures as \pm SEM with error bars unless otherwise indicated. Current traces were refiltered at $1 \mathrm{kHz}$ for presentation.

Experimental design and statistical analysis. To determine whether NMDAR inhibition depends on glutamate concentration (see Fig. 1, Table 1), we used a two-way ANOVA with Tukey's post hoc analysis to compare drug $\mathrm{IC}_{50}$ values depending on the NMDAR subtype and the glutamate concentration, with $n=4-7$ cells in each group. We performed separate two-way ANOVAs for memantine and ketamine.

To compare the $10-90 \%$ rise times and decay $\tau_{\mathrm{w}}$ for synaptic-like glutamate applications (see Table 2), we used a one-way repeatedmeasures ANOVA with $n=5-6$ cells in each group. We performed separate one-way ANOVAs for each NMDAR subtype and drug combination.

To determine whether NMDAR inhibition depends on the duration of glutamate exposure (see Figs. 3, 7B), we used a two-way repeated-measures ANOVA with Bonferroni correction to compare $I_{\text {drug }} / I_{\text {control }}$ values depending on the duration of glutamate exposure as a repeated measure and on NMDAR subtype, which was not a repeated measure, with $n=4-6$ cells in each group. We performed separate two-way ANOVAs for memantine and ketamine.

To determine whether recovery from desensitization differs in the presence of drug (see Figs. 6, 7A), we used a one-way ANOVA with Tukey's post hoc analysis to compare each normalized $I_{\text {peak }}$ in control, memantine, and ketamine and the $\tau_{\mathrm{w}}$ or $\tau$ of the time course of recovery from desensitization in control, memantine, and ketamine, with $n=$ $5-11$ cells in each group.

To determine whether memantine inhibition of GluN1/2A receptors expressed in tsA201 cells depended on $\mathrm{Ca}^{2+}$ (see Fig. 7C,D), we performed a one-way ANOVA with Tukey's post hoc analysis to compare memantine $\mathrm{IC}_{50}$ values in normal, high-, and low- $\mathrm{Ca}^{2+}$ conditions, with $n=5$ cells in each group. To determine whether memantine inhibition of synaptic NMDAR responses in mouse cortical pyramidal neurons depended on $\mathrm{Ca}^{2+}$ (see Fig. $7 E-G$ ), we performed a two-tailed Student's $t$ test to compare memantine inhibition $\left(I_{\text {drug }} / I_{\text {control }}\right)$ in high- and low$\mathrm{Ca}^{2+}$ conditions, with $n=5-6$ cells and 1 cell per slice. We compared the PPR across all conditions using a one-way ANOVA with Tukey's post hoc analysis, with $n=5-6$ cells and 1 cell per slice. 


\section{Results}

Glutamate concentration does not affect inhibition by memantine or ketamine strongly

The maximum extracellular glutamate concentration is likely to differ considerably between synaptic and extrasynaptic regions. Synaptic NMDARs are exposed to $\sim 1 \mathrm{~mm}$ glutamate briefly after a presynaptic action potential (Clements et al., 1992), whereas extrasynaptic NMDARs experience submicromolar to low micromolar glutamate (Herman and Jahr, 2007; Le Meur et al., 2007). It is unclear whether NMDAR inhibition by memantine or ketamine depends on the glutamate concentration. Memantine potency has been shown to increase with increasing NMDA concentration (Chen et al., 1992), which may suggest greater inhibition of synaptic NMDARs, but other reports have shown memantine potency not to depend on agonist concentration (Gilling et al., 2007; Gilling et al., 2009). To our knowledge, no studies have addressed the dependence of ketamine potency on glutamate concentration.

The typical NMDAR subunit composition also may differ at synaptic and extrasynaptic sites. NMDARs are four-subunit complexes generally containing GluN1 and GluN2 subunits. The four GluN2 subunits (GluN2A-GluN2D) vary in expression based on the brain region, cell type, and developmental stage (Traynelis et al., 2010; Paoletti et al., 2013; Glasgow et al., 2015). NMDAR subtype is defined by the receptor's subunit combination. Here, we focus on inhibition of the GluN1/2A receptor subtype (NMDARs composed of GluN1 and GluN2A subunits) and GluN1/2B receptors for two reasons. First, many studies have suggested that GluN2A subunits are expressed preferentially at synaptic sites, whereas GluN2B subunits are expressed preferentially at extrasynaptic sites (Hardingham and Bading, 2010; Paoletti et al., 2013; Parsons and Raymond, 2014). Note, however, that the segregation is not complete and also that many NMDARs are likely to be triheteromers that contain both GluN2A and GluN2B subunits (Gray et al., 2011; Tovar et al., 2013). Second, the hypothesis that neuroprotection by memantine results from preferential inhibition of extrasynaptic receptors has been based mostly on studies of excitatory neurons that express predominantly GluN1, GluN2A, and GluN2B subunits (Papp et al., 2008; Okamoto et al., 2009; Milnerwood et al., 2010; Kaufman et al., 2012; Dau et al., 2014). GluN2C and GluN2D subunits expressed on other types of neurons nevertheless are likely to play important roles in many of the effects of memantine and ketamine (Kotermanski and Johnson, 2009; Wild et al., 2013; Povysheva and Johnson, 2016). We started by determining whether dependence on glutamate concentration of GluN1/2A or GluN1/2B receptor inhibition by memantine or ketamine could underlie preferential inhibition of synaptic or extrasynaptic NMDARs.

We expressed GluN1/2A or GluN1/2B receptors in tsA201 cells and measured the $\mathrm{IC}_{50}$ of memantine or ketamine when NMDARs were activated by either $1 \mathrm{~mm}$ or $0.3 \mu \mathrm{M}$ glutamate. We chose a saturating concentration of $1 \mathrm{~mm}$ glutamate to mimic the glutamate concentration at synaptic NMDARs during synaptic transmission. We chose $0.3 \mu \mathrm{M}$ glutamate as the lower concentration because it is within the range of extrasynaptic glutamate concentration estimates ( $\sim 20 \mathrm{nM}$ to $2 \mu \mathrm{M}$ ) (Le Meur et al., 2007). This concentration is also well below $(\sim 10$-fold $)$ the glutamate $\mathrm{EC}_{50}$ for GluN1/2A and GluN1/2B receptors and produces small but measurable responses. It is important to compare glutamate concentrations well above and well below the $\mathrm{EC}_{50}$; for channel blockers that exhibit agonist concentration dependence of $\mathrm{IC}_{50}$, blocker $\mathrm{IC}_{50}$ should depend on the channel open probability (not on absolute agonist concentration; Johnson and Qian, 2002; Blanpied et al., 2005). Because our chosen glutamate concentrations sample vastly different channel open probabilities, our experiments are well suited to detect dependence of memantine and ketamine potency on the glutamate concentration.

We found that inhibition of GluN1/2A and GluN1/2B receptors by memantine depended slightly but significantly on glutamate concentration and in opposite directions depending on the NMDAR subtype (GluN1/2A, $p=0.0009$; GluN1/2B, $p=$ 0.0051; two-way ANOVA with Tukey's post hoc analysis; Fig. $1 A, B$, Table 1). In contrast, we found that inhibition of GluN1/2A and GluN1/2B receptors by ketamine did not depend on glutamate concentration (GluN1/2A, $p=0.43$; GluN1/2B, $p=0.46$; two-way ANOVA with Tukey's post hoc analysis; Fig. $1 C, D$, Table 1). Although memantine inhibition depends on glutamate concentration, vastly different glutamate concentrations cause only small changes in memantine $\mathrm{IC}_{50}$. Our results are in general agreement with those of Gilling et al. (2007 and 2009), which reported no agonist dependence of memantine $\mathrm{IC}_{50}$ when measured over a smaller agonist concentration range. Our results appear inconsistent with those of Chen et al. (1992), which reported much greater agonist concentration dependence of memantine potency.

Interestingly, we found that inhibition by memantine or ketamine depended weakly upon the NMDAR subtype, with GluN1/2A displaying higher $\mathrm{IC}_{50}$ values than previously determined by us (Kotermanski and Johnson, 2009; Kotermanski et al., 2009; Table 1). A potentially important difference in recording conditions is the addition here of $10 \mu \mathrm{M}$ EDTA to the extracellular solutions to chelate contaminating $\mathrm{Zn}^{2+}$, which inhibits GluN1/2A receptors with nanomolar affinity (Paoletti et al., 1997). Because $\mathrm{Zn}^{2+}$ increases NMDAR sensitivity to inhibition by protons, and memantine and ketamine $\mathrm{IC}_{50}$ values decrease at lower pH (Dravid et al., 2007), our use of EDTA could have led to the higher GluN1/2A receptor $\mathrm{IC}_{50}$ values for memantine and ketamine reported here. Nevertheless, lower memantine and ketamine $\mathrm{IC}_{50}$ values at GluN1/2B receptors could underlie some preferential inhibition of extrasynaptic NMDARs.

\section{Inhibition depends on duration of glutamate exposure and on NMDAR subtype}

Synaptic NMDARs are transiently exposed to $\sim 1$ mM glutamate for $\sim 1-2$ ms (Clements et al., 1992). In contrast, extrasynaptic NMDARs are likely to be exposed to glutamate for much longer periods or tonically (Fellin et al., 2004; Herman and Jahr, 2007; Le Meur et al., 2007; Harris and Pettit, 2008; Povysheva and Johnson, 2012; Riebe et al., 2016), which allows extrasynaptic NMDARs to reach steady-state activation. Whether inhibition of NMDARs by memantine or ketamine depends on the duration of glutamate exposure is unknown, although memantine inhibition of synaptic NMDARs increases with stimulation frequency (Wild et al., 2013). Therefore, we investigated whether inhibition by memantine or ketamine depends on NMDAR subtype and on the duration of glutamate exposure.

We performed whole-cell recordings from tsA201 cells expressing GluN1/2A or GluN1/2B receptors held at $-65 \mathrm{mV}$. To achieve brief, synaptic-like glutamate applications $(\sim 2.5 \mathrm{~ms})$, we performed recordings from cells lifted off the coverslip on which they were cultured, which permitted rapid and complete solution exchange (Fig. 2; see Materials and Methods). The time course of currents activated by synaptic-like glutamate applications to cells expressing GluN1/2A or GluN1/2B receptors (Fig. 2C,D, Table 2) 
A
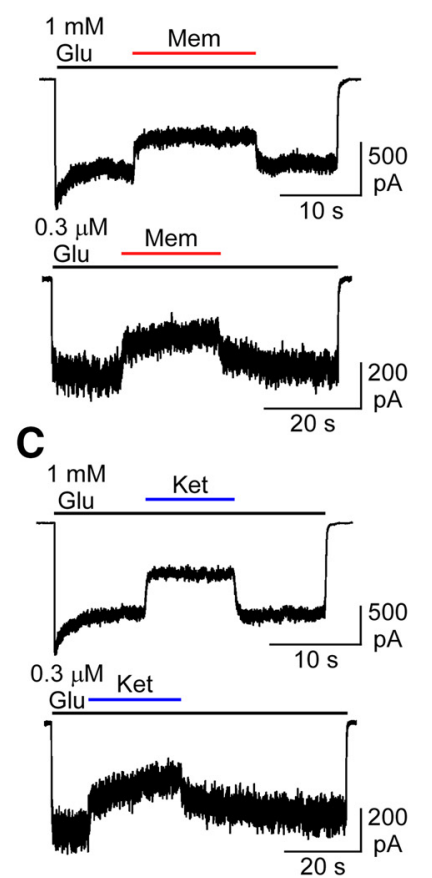

GluN1/2A

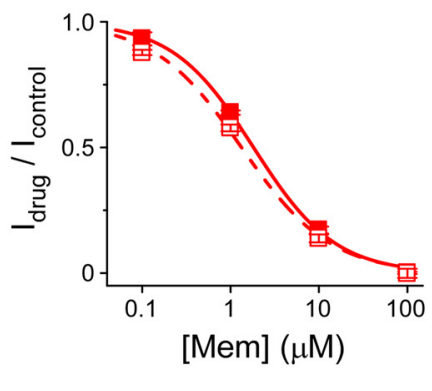

$1 \mathrm{mM} \mathrm{Glu} \longrightarrow$ - GluN1/2A

$0.3 \mu \mathrm{M}$ Glu $-\square-$ GluN1/2A

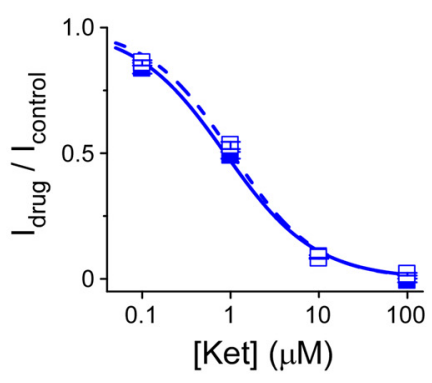

B
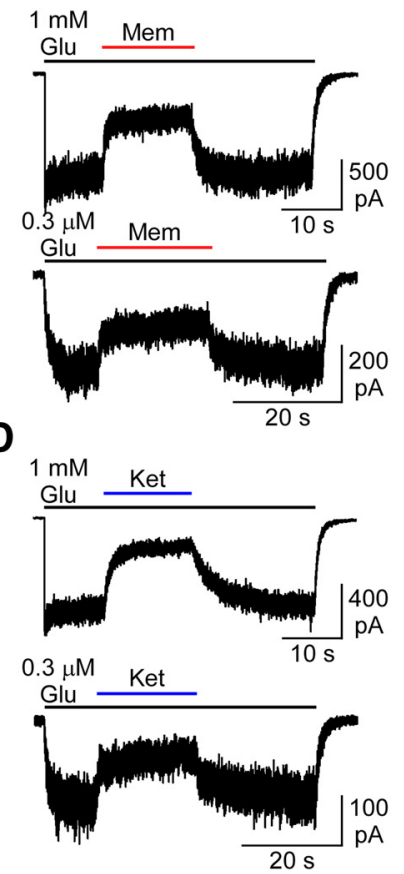

GluN1/2B

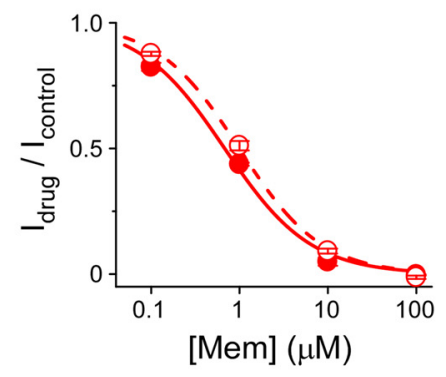

$1 \mathrm{mM} \mathrm{Glu} \longrightarrow$ GluN1/2B

$0.3 \mu \mathrm{M} \mathrm{Glu}-\mathrm{O}-\mathrm{GluN} 1 / 2 \mathrm{~B}$

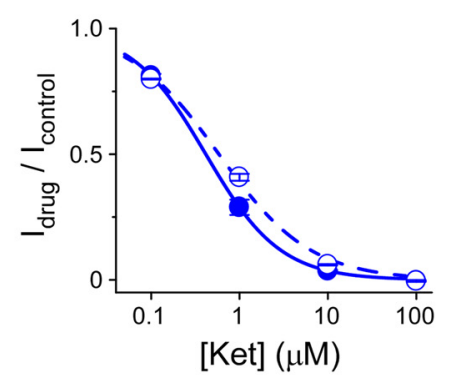

Figure 1. Glutamate (Glu) concentration does not strongly affect inhibition by memantine (Mem) or ketamine (Ket). $\boldsymbol{A}, \boldsymbol{B}$, Left, Representative current traces from cells transfected with GluN1/2A $(\boldsymbol{A})$ or GluN1/2B $(\boldsymbol{B})$ receptors during activation by $1 \mathrm{~mm}$ glutamate (top traces) or $0.3 \mu \mathrm{m}$ glutamate (bottom traces) and inhibition by $1 \mu \mathrm{m}$ memantine (red bar). $\boldsymbol{A}, \boldsymbol{B}$, Right, Mean concentrationinhibition relations for memantine inhibition of GluN1/2A ( $A)$ or GluN1/2B (B) receptors. $\boldsymbol{C}, \boldsymbol{D}$, Same as in $\boldsymbol{A}$ and $\boldsymbol{B}$ except for $1 \mu \mathrm{m}$ ketamine inhibition (blue bars) of GluN1/2A (C) or GluN1/2B (D) receptors. Time of application of glutamate is indicated by black bars above traces. Means represent $n=4-7$ cells. Error bars are smaller than symbols in some panels. IC ${ }_{50}$ and $n_{\mathrm{H}}$ values are given in Table 1.

Table 1. Effect of glutamate concentration on memantine and ketamine $\mathrm{IC}_{50}$

\begin{tabular}{|c|c|c|c|c|c|c|c|c|c|}
\hline \multirow[b]{2}{*}{ Drug } & \multirow[b]{2}{*}{ [Glutamate] } & \multicolumn{4}{|l|}{ GluN1/2A } & \multicolumn{4}{|l|}{ GluN1/2B } \\
\hline & & $\mathrm{IC}_{50}(\mu \mathrm{M})$ & \pm SEM & $n_{\mathrm{H}}$ & \pm SEM & $\mathrm{IC}_{50}(\mu \mathrm{M})$ & \pm SEM & $n_{\mathrm{H}}$ & \pm SEM \\
\hline \multirow[t]{2}{*}{ Memantine } & $0.3 \mu \mathrm{M}$ & $1.33^{a, b}$ & 0.05 & 0.87 & 0.05 & $1.02^{a, b}$ & 0.06 & 0.93 & 0.03 \\
\hline & $1 \mathrm{~mm}$ & $1.82^{a, b}$ & 0.06 & 0.94 & 0.02 & $0.68^{a, b}$ & 0.03 & 0.89 & 0.04 \\
\hline \multirow[t]{2}{*}{ Ketamine } & $0.3 \mu \mathrm{M}$ & $1.03^{b}$ & 0.06 & 0.91 & 0.02 & $0.59^{b}$ & 0.03 & $0.83^{a}$ & 0.01 \\
\hline & $1 \mathrm{~mm}$ & $0.89^{b}$ & 0.07 & 0.86 & 0.05 & $0.43^{b}$ & 0.04 & $1.04^{a}$ & 0.05 \\
\hline
\end{tabular}

$\mathrm{IC}_{50}$ and $n_{\mathrm{H}}$ values were derived from fits (see Materials and Methods) to data from individual cells. The indicated glutamate concentration ([Glutamate]) was used to activate NMDARs at $-65 \mathrm{mV}$ for collection of concentration-inhibition data. $n=4-7$ cells for each group.

${ }^{a} p<0.05$ between $0.3 \mu \mathrm{m}$ and $1 \mathrm{~mm}$ glutamate for the same NMDAR subtype by two-way ANOVA with Tukey's post hoc analysis.

${ }^{b} p<0.05$ between GluN1/2A and GluN1/2B receptors for the same glutamate concentration by two-way ANOVA with Tukey's post hoc analysis.

were consistent with outside-out patch currents recorded from HEK 293 cells expressing the same NMDAR subtype activated by brief glutamate applications (Erreger et al., 2005). Our response time course also was similar to the time course of EPSCs recorded from cultured neurons expressing predominantly the same NMDAR subtype (Gray et al., 2011; Tovar et al., 2013). Synapticlike glutamate applications were delivered at $0.2 \mathrm{~Hz}$ to allow receptor deactivation and recovery from desensitization between applications (Fig. 2C,D, Table 2).

NMDAR inhibition by open channel blockers such as memantine and ketamine requires channel opening. Therefore, measurement of a steady level of inhibition of responses to synaptic-like glutamate applications required use of a protocol involving multiple coapplications of agonist and drug. We measured a steady level of memantine and ketamine inhibition of peak NMDAR currents using the protocol outlined in Figure 3 and described in the Materials and Methods. We also measured inhibition by memantine and ketamine during long glutamate applications ( $>45 \mathrm{~s}$ ) using a standard protocol (Fig. 3A-D) and compared inhibition during synaptic-like and long glutamate applications within the same cell. We measured fractional current during inhibition by $1 \mu \mathrm{M}$ memantine or $0.5 \mu \mathrm{M}$ ketamine, concentrations near $\mathrm{IC}_{50}$ values for the GluN1/2A and GluN1/2B receptor responses to long glutamate applications (Table 1 ). We chose concentrations near drug $\mathrm{IC}_{50}$ so that any differences between the potency of inhibition of synaptic-like and long glutamate applications would be sensitively reflected by differences in fractional current.

We found that memantine and ketamine inhibition during synaptic-like glutamate applications can differ significantly from inhibition during long glutamate applications and that this difference depends on the NMDAR subtype (Fig. 3E). A $1 \mu \mathrm{M}$ memantine concentration inhibited GluN1/2A receptors significantly less during synaptic-like glutamate applications than during long glutamate applications, but inhibited GluN1/2B receptors similarly during synaptic-like and long glutamate applications (GluN1/2A, $p=0.003$; GluN1/2B, $p=0.23$; two-way repeated-measures ANOVA with Bonferroni correction; Fig. $3 A, B, E)$. In contrast, $0.5 \mu \mathrm{M}$ ketamine inhibited GluN1/2A receptors similarly during synaptic-like and long glutamate appli- 
cations, but inhibited GluN1/2B receptors significantly more during synaptic-like glutamate applications than during long glutamate applications (GluN1/2A, $p=$ 0.99; GluN1/2B, $p=0.001$; two-way repeated-measures ANOVA with Bonferroni correction; Fig. $3 C-E$ ). We also found that inhibition by memantine and ketamine depended on the NMDAR subtype during synaptic-like but not during long glutamate applications (synaptic-like applications: memantine, $p=0.0005$; ketamine, $p=0.036$; long applications: memantine, $p=0.27$; ketamine, $p=0.99$; two-way repeated-measures ANOVA with Bonferroni correction; Fig. 3E). Therefore, inhibition by both memantine and ketamine depends on the duration of glutamate exposure in an NMDARsubtype-dependent manner.

We also examined the time course of responses to synaptic-like glutamate applications and found that neither memantine nor ketamine alters activation or deactivation kinetics of GluN1/2A or GluN1/2B receptors significantly $(p>0.05$, one-way repeatedmeasures ANOVA; Table 2). Our findings differ from those of a study of inhibition by memantine and ketamine in cultured hippocampal neurons (Emnett et al., 2013), in which NMDAR EPSC deactivation kinetics were faster in the presence of memantine or ketamine. Two differences in experimental conditions may explain the divergent results. First, Emnett et al. (2013) used much higher concentrations of memantine and ketamine $(10 \mu \mathrm{M})$, which would result in faster block of open channels and potentially faster apparent deactivation kinetics. Second, Emnett et al. (2013) used cultured hippocampal neurons, which contain a mixed population of GluN2A- and GluN2B-containing receptors (Paoletti et al., 2013). Because GluN1/2A receptors display much faster deactivation kinetics than GluN1/2B re-

ceptors (Paoletti et al., 2013; Glasgow et al., 2015), acceleration of NMDAR EPSC deactivation by memantine and ketamine could reflect preferential inhibition of GluN1/2B receptors, as we observed during synaptic-like glutamate applications (Fig. 3E).

\section{Memantine enhances desensitization of GluN1/2A receptors}

We next focused on the drug and NMDAR subtype combination with the largest discrepancy between inhibition of responses to synaptic-like and long glutamate applications, inhibition by memantine of GluN1/2A receptors. We used kinetic models to investigate mechanisms by which inhibition by a channel blocker could depend on the duration of glutamate exposure. The utility of complex open channel block models for exploration of mechanism can be limited by the large number of adjustable rate constants that can be difficult to constrain experimentally. We therefore first used an open channel blocker model based on a simplified NMDAR model (Clements and Westbrook, 1991) that

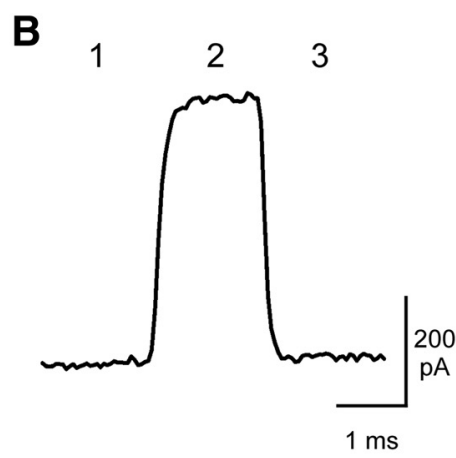

Figure 2. Synaptic-like glutamate applications to lifted transfected cells. $A$, Schematic of fast perfusion system depicting three ass barrels that contain normal extracellular solution alone (control) or with $1 \mathrm{~mm}$ glutamate added (Glu). Arrows positon 10 3 and from barrel position 3 to 1. B, Open pipette recordings of junction current relaxation during movement of barrels , whe barrel 2 solution $\sim 50 \%$ lower osmolality that the barrel 1 and 3 solution. $C, D$, Representative current traces from the first of the synaptic-like glutamate applications shown on the right, which were repeated at $0.2 \mathrm{~Hz}$.

Table 2. Time course of NMDAR responses to synaptic-like glutamate applications

\begin{tabular}{|c|c|c|c|c|c|}
\hline \multirow{2}{*}{$\begin{array}{l}\text { NMDAR } \\
\text { subtype }\end{array}$} & \multirow[b]{2}{*}{ Condition } & \multicolumn{2}{|c|}{$\begin{array}{l}10-90 \% \text { Rise } \\
\text { time (ms) }\end{array}$} & \multicolumn{2}{|c|}{ Decay $\tau_{\mathrm{w}}$ (ms) } \\
\hline & & Average & \pm SEM & Average & \pm SEM \\
\hline \multirow{6}{*}{ GluN1/2A } & Control & 4.50 & 0.34 & 31.5 & 3.85 \\
\hline & Memantine & 4.63 & 0.49 & 28.5 & 3.25 \\
\hline & Recovery & 4.72 & 0.41 & 33.3 & 3.73 \\
\hline & Control & 3.99 & 0.27 & 36.9 & 1.29 \\
\hline & Ketamine & 4.08 & 0.35 & 36.1 & 1.58 \\
\hline & Recovery & 3.76 & 0.32 & 39.5 & 2.07 \\
\hline \multirow[t]{6}{*}{ GluN1/2B } & Control & 17.6 & 2.38 & 400 & 47.2 \\
\hline & Memantine & 21.0 & 1.66 & 361 & 53.0 \\
\hline & Recovery & 17.4 & 2.45 & 369 & 43.5 \\
\hline & Control & 24.0 & 3.41 & 456 & 60.3 \\
\hline & Ketamine & 25.3 & 3.12 & 423 & 63.5 \\
\hline & Recovery & 18.3 & 3.34 & 425 & 64.6 \\
\hline
\end{tabular}

Neither NMDAR activation nor deactivation kinetics in response to synaptic-like glutamate applications differed significantly $(p>0.05)$ when compared in the absence and presence of $1 \mu \mathrm{m}$ memantine or $0.5 \mu \mathrm{m}$ ketamine by one-way repeated measures ANOVAs. $n=5-6$ for all groups. 
A
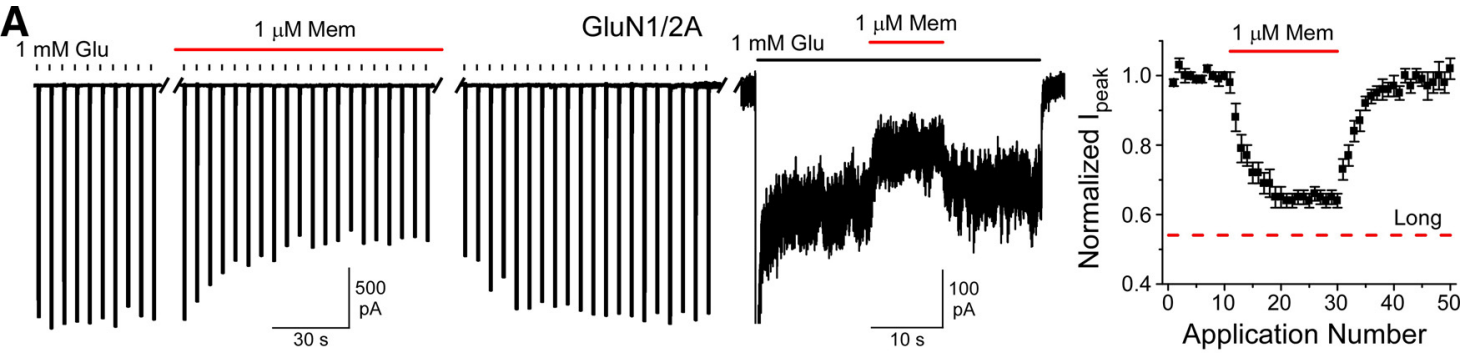

B

$1 \mu \mathrm{M}$ Mem

GluN1/2B
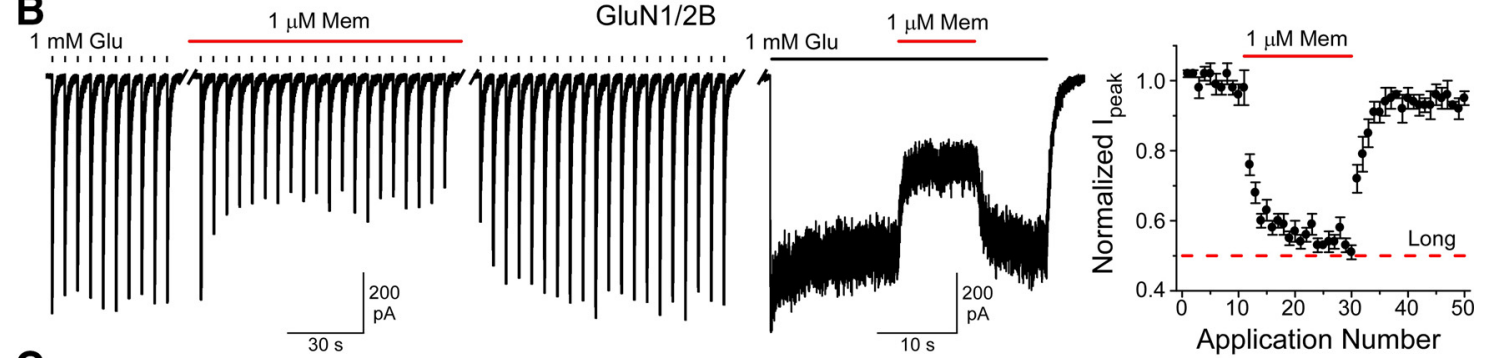

${ }_{1 \mathrm{mM} \mathrm{Glu}}^{\text {C }}$

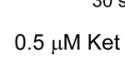

GluN1/2A
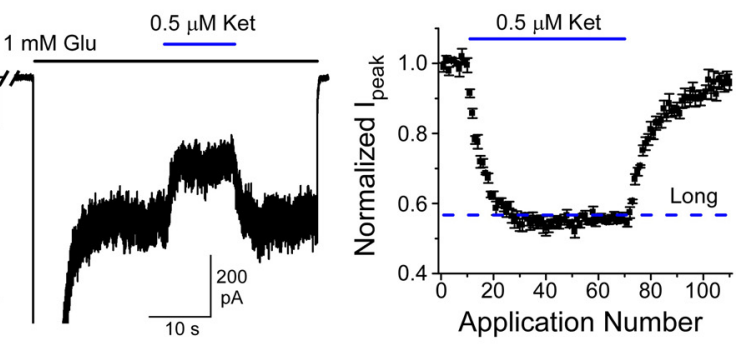

D
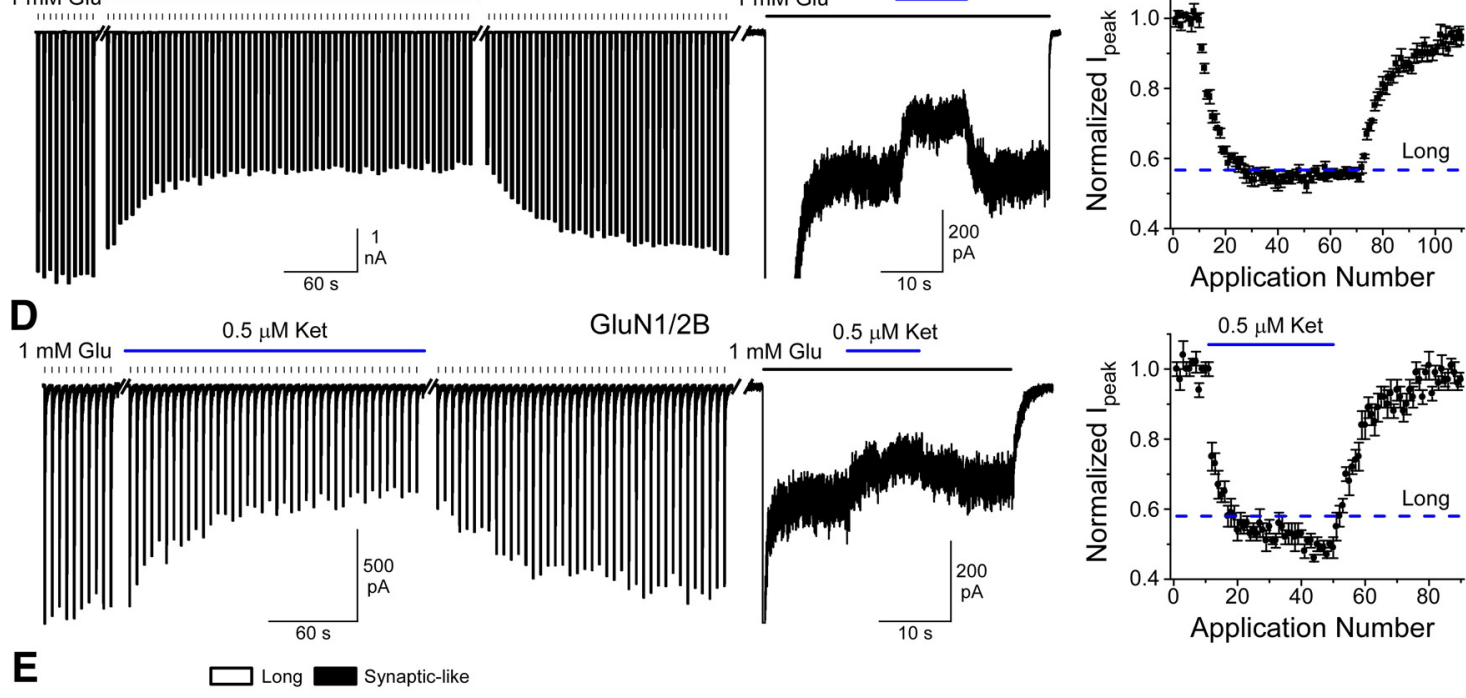

E
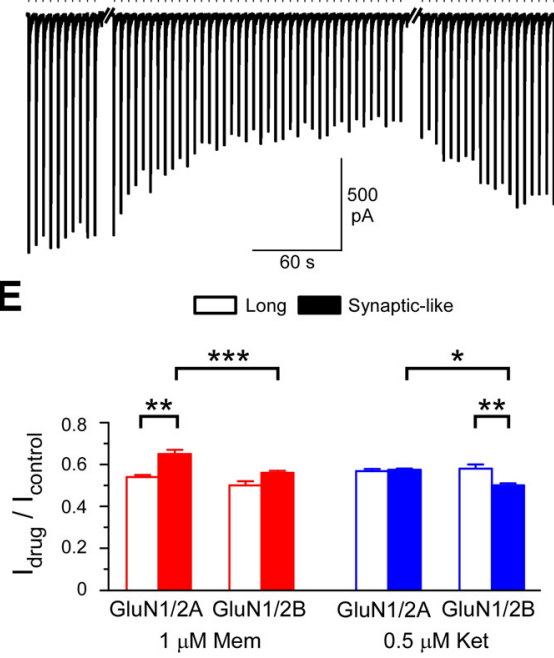

Figure 3. Inhibition by memantine and ketamine depends on duration of glutamate exposure in an NMDAR-subtype-dependent manner. $\boldsymbol{A}, \boldsymbol{B}$, Memantine inhibition of GluN1/2A $(\boldsymbol{A})$ and GluN1/2B (B) receptors. Representative current traces from a lifted cell expressing GluN1/2A receptors in response to synaptic-like (left) or long (center) glutamate applications (black lines above current traces) in the absence or presence of memantine (red bars). Some peak responses during long glutamate applications were truncated to better display steady-state current after desensitization. Right, Plot of mean peak current ( $I_{\text {peak }}$; see Materials and Methods; black symbols) during synaptic-like glutamate applications normalized to the average of the $I_{\text {peak }}$ in response to the first 10 synaptic-like glutamate applications. Red dashed line indicates mean normalized steady-state current in memantine during long glutamate applications. $\boldsymbol{C}, \boldsymbol{D}$, Same as in $\boldsymbol{A}$ and $\boldsymbol{B}$ except for ketamine inhibition (blue bars, blue dashed lines). Inhibition during synaptic-like and long glutamate applications are from the same cell; $n=5-6$ cells for each group. $\boldsymbol{E}$, Mean $I_{\text {drug }} / I_{\text {control }}$ for memantine and ketamine inhibition of GluN1/2A and GluN1/2B receptors during synaptic-like and long glutamate applications. Groups were compared by two-way repeated-measures ANOVA with Bonferroni correction; ${ }^{\star} p<0.05 ;{ }^{\star \star} p<0.01 ;{ }^{\star \star \star} p<0.001$.

accounts for agonist binding, channel opening, and desensitization (model 1; Fig. 4A). In this model, only glutamate (agonist, A) binding is depicted because all of our experiments were conducted in the continuous presence of a saturating concentration of glycine. Memantine and ketamine are both open channel blockers that can be at least partially trapped after binding (Blan- pied et al., 1997; Chen and Lipton, 1997; Sobolevsky et al., 1998; Mealing et al., 1999; Kotermanski et al., 2009). Open channel blockers can only bind and unbind from the receptor when the channel is open. Trapping open channel blockers permit channel closure and agonist dissociation while the blocker is bound, thereby trapping the blocker (Johnson et al., 2015). The blocked 
A

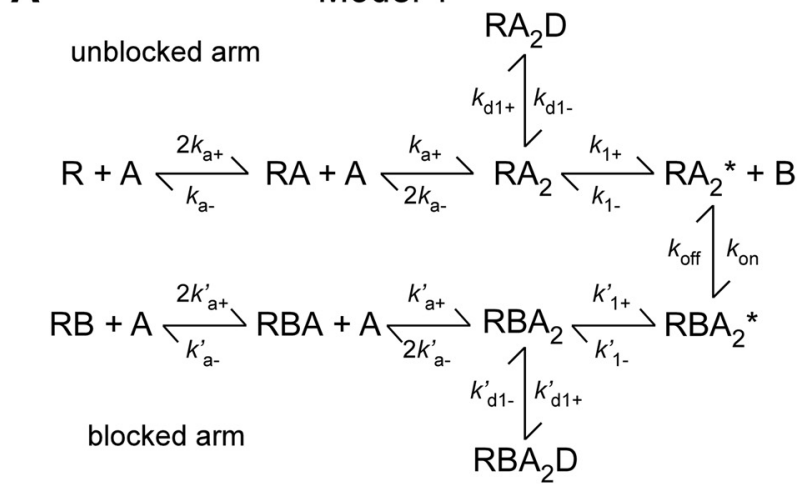

C

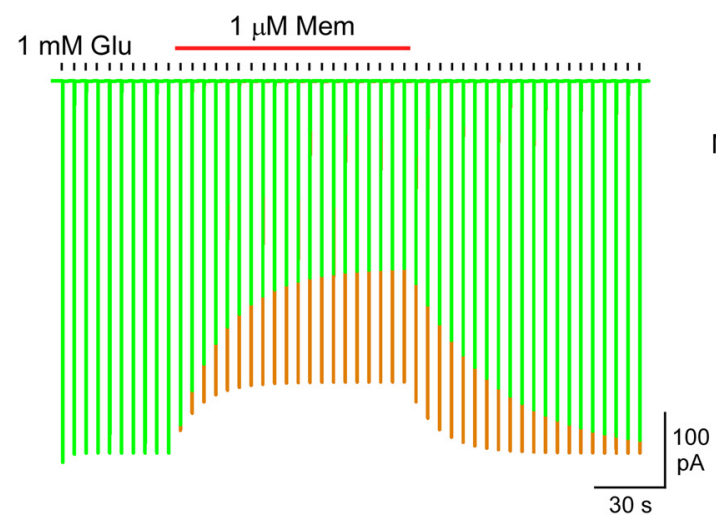

B

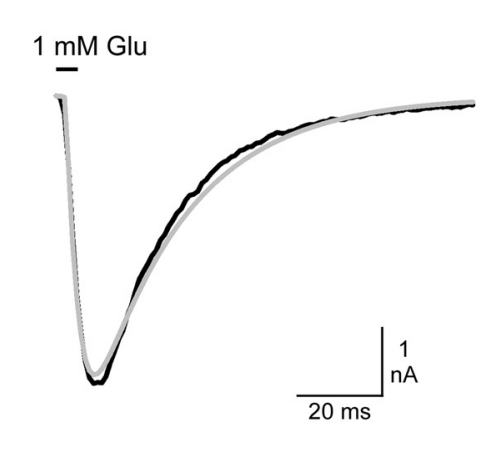

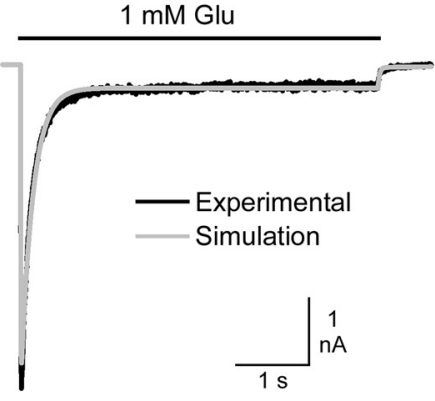

D

Model 1 Simulations

- Symmetric

$k_{\mathrm{d} 1+}^{\prime}, k_{\text {off }} \uparrow 5 \mathrm{x}$

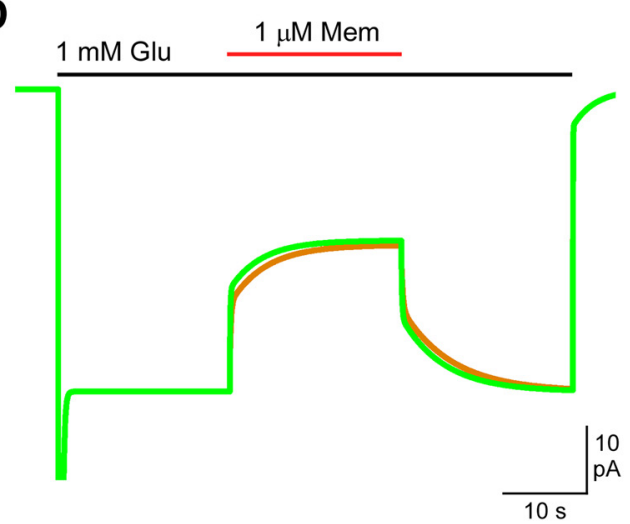

Figure 4. Model 1 suggests that memantine alters state transitions of GluN1/2A receptors. $A$, Simple GluN1/2A receptor trapping block model (model 1 ) used to investigate mechanism of inhibition by memantine (blocker, $B)$. The receptor $(R)$ binds two glutamate $(A)$ molecules and then can enter a desensitized state $\left(R A_{2} D\right)$ or an open state $\left(R A_{2}^{*}\right)$. The top unblocked arm describes receptor function in the absence of memantine, whereas the lower blocked arm describes receptor function with memantine bound. The transition between unblocked and blocked arms (rate constants $k_{\text {on }}$ and $k_{\text {off }}$ ) represents memantine binding and unbinding. $\boldsymbol{B}$, Experimentally recorded currents (black traces) of GluN1/2A receptors activated by synaptic-like (left) or long (right) applications of $1 \mathrm{~mm}$ glutamate in the absence of memantine, with model 1 simulations (gray traces) overlaid. C, D, Examples of model 1 simulations of memantine inhibition during synaptic-like glutamate applications $(\boldsymbol{C})$ and during a long glutamate application (D). Model 1 was either constrained to be symmetric (corresponding blocked arm and unblocked arm rates forced to be equal; green traces), or $k_{\mathrm{d} 2+}^{\prime}$ was increased (up arrow) 5 -fold (5X; orange traces) and $k_{\text {off }}$ adjusted to maintain memantine $\mathrm{IC}_{50}$ for inhibition of long glutamate applications close to $1 \mu \mathrm{m}$. Time of application of glutamate is indicated by black bars above traces and application of memantine is indicated by red bars above traces.

receptor can access all the states available to unblocked receptors (Fig. 4A). The inhibitory properties of many open channel blockers depend, not only on block of current flow, but also on alteration of transition rates between receptor states while the blocker is bound in the channel (Johnson and Qian, 2002; Johnson et al., 2015). We examined the hypothesis that transition rates between receptor states are altered while memantine blocks the channel, thereby causing the observed dependence of memantine inhibition on the duration of glutamate exposure.

We used model 1 (Fig. 4B; see Materials and Methods) to simulate experiments in which we measured inhibition during synaptic-like and long glutamate applications (Fig. 4C,D, Table $3)$. We first examined the characteristics of model 1 when constrained to be a "symmetric model." In a symmetric model, channel occupation by a blocker does not affect transition rates; therefore, rates in the upper, unblocked arm are equal to the corresponding rates in the lower, blocked arm. We found that current simulations with a symmetric version of model 1 predicted that inhibition during synaptic-like glutamate applications should be identical to inhibition during long glutamate applications, which is inconsistent with our experimental results (Fig. 4C,D, Table 3). Poor agreement between the symmetric model and our experimental results suggests that the presence of memantine in the channel alters transition rates between receptor states, as proposed previously (Blanpied et al., 1997; Chen and Lipton, 1997).
Table 3. Model 1 blocked arm rates affect memantine inhibition

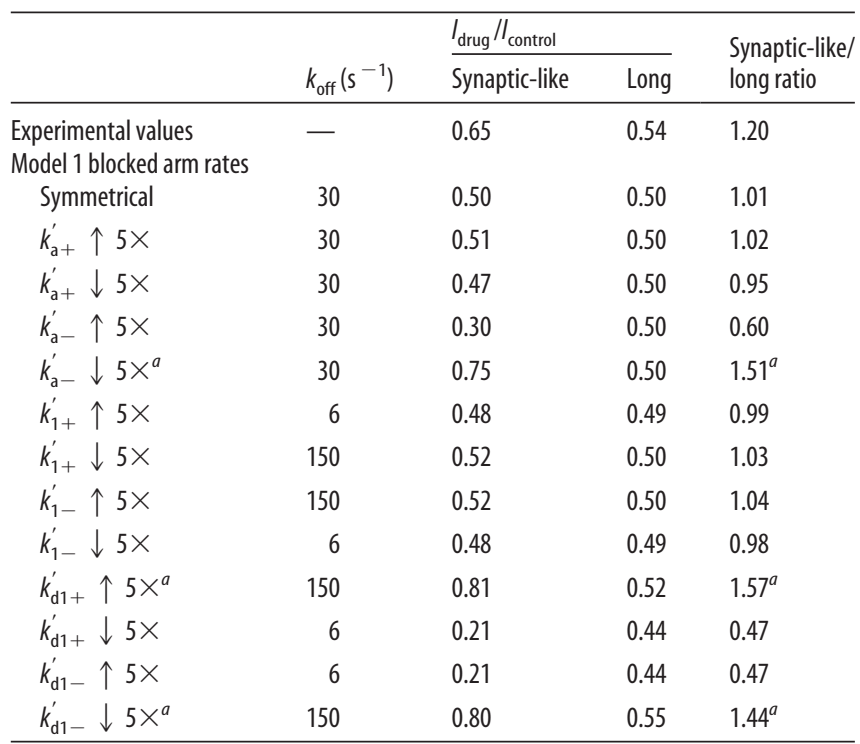

GluN1/2A receptor Model 1 blocked arm rates were individually increased (up arrow) or decreased (down arrow) 5 -fold $(5 \times)$ from the unblocked arm rates (see Materials and Methods). Model 1 simulations (example in Fig. $4 C, D$ ) were used to calculate $I_{\text {drug }} / I_{\text {control }}$ as described in the Materials and Methods.

${ }^{a}$ Model 1 blocked arm rate change that caused a substantial increase in the synaptic-like/long ratio; also, the corresponding synaptic-like/long ratio. 
We next investigated whether an asymmetric model, a model in which corresponding unblocked and blocked arm rates differ, could reproduce our experimental observation that memantine inhibition depends on the duration of glutamate exposure. We simulated inhibition by memantine during synaptic-like and long glutamate applications using model 1 and either increased or decreased each of the blocked arm rates fivefold (Fig. 4C,D, Table 3). For ease of comparison, we calculated the ratio of inhibition during synaptic-like glutamate applications to inhibition during long applications (synaptic-like/long ratio; Table 3). We found that modification of any of multiple transition rates in the blocked arm could cause memantine inhibition to depend on the duration of glutamate exposure. Three of the transition rate modifications caused the synaptic-like/ long ratio to increase substantially, consistent with the change observed experimentally (Table 3 ). Therefore, our model 1 results suggest that the dependence of memantine inhibition on duration of glutamate exposure could be due to memantine in the channel altering one or more of the transition rates identified in Table 3.

Model 1 does not adequately capture more complex aspects of NMDAR function, including its multiple desensitized states. Therefore, we performed simulations using a more detailed kinetic model (Banke and Traynelis, 2003; Erreger et al., 2005), which we optimized and then expanded to include a blocked arm (model 2; Fig. 5A; see Materials and Methods). Model 2 has an additional desensitized state $\left(\mathrm{RA}_{2} \mathrm{D}_{2}\right)$ as well as two additional pre-open states $\left(\mathrm{RA}_{2} 1\right.$ and $\left.\mathrm{RA}_{2} 2\right)$, which increases the number of unconstrained rates in the blocked arm. It was not feasible to fit our experimental recordings using model 2 with all blocked arm rates free to vary because the large number of free variables led to inadequately constrained fits. We therefore used our model 1 results as a guide to limit the number of adjustable parameters in model 2 and to improve the reliability of its predictions. Because modification of the model 1 blocked arm agonist binding $\left(k_{\mathrm{a}_{+}}^{\prime}\right)$ and gating $\left(k_{1+}^{\prime}, k_{1-}^{\prime}\right)$ rates did not substantially increase the synaptic-like/long ratio (Table 3 ), the corresponding model 2 rates $\left(k_{\mathrm{a}+}^{\prime}, k_{1+}^{\prime}, k_{1-}^{\prime}, k_{2+}^{\prime}, k_{2-}^{\prime}\right)$ were initially fixed at unblocked arm values. We fit model 2 to experimental recordings while allowing combinations of the agonist unbinding rate $\left(k_{\mathrm{a}-}^{\prime}\right)$ and/or the desensitization rates $\left(k_{\mathrm{d} 1+/-}^{\prime}\right.$ and $\left.k_{\mathrm{d} 2+/-}^{\prime}\right)$ to vary (Table 4$)$. In addition, the memantine unbinding rate, $k_{\text {off }}$, was allowed to vary in each fit because $k_{\text {off }}$ has not been estimated experimentally and its value is constrained in fits by fractional current in memantine.

As we found with model 1, when model 2 was forced to be symmetric, simulations were in poor agreement with our experimental recordings (Fig. $5 B-D$, Table 4). We next examined asymmetric models. Notably, when fits were performed with $k_{\text {off }}$ and only one or two additional rate constants free, best fits were achieved only when the additional free rate constants altered desensitization (models 2e and $2 \mathrm{k}$; Table 4). For all fits in which any desensitization rate(s) were free, best fits were achieved when desensitization rate changes caused increased occupancy of blocked arm desensitized states (Table 4), implying that memantine stabilizes desensitized states. The best fit was achieved with model $2 \mathrm{p}$, which had six free rate constants $\left(k_{\mathrm{off}}, k_{\mathrm{a}-}^{\prime}, k_{\mathrm{d} 1+/-}^{\prime}\right.$, and $k_{\mathrm{d} 2+/-}^{\prime}$; Fig. $5 B-D$, Tables 4,5$)$. However, models $2 \mathrm{k}$ and $2 \mathrm{l}$, in which only two desensitization rate constants and $k_{\text {off }}$ were free, produced fits almost identical to model $2 p$ (Table 4 ). Therefore, results of kinetic modeling suggest that memantine binding pref- erentially inhibits GluN1/2A receptor responses activated by long glutamate applications primarily by increasing desensitization, with a possible effect also on agonist unbinding.

As noted above, $k_{\text {off }}$ was allowed to vary during fitting to achieve appropriate levels of memantine inhibition. We would therefore expect that changes in desensitization parameters that tend to decrease $\mathrm{IC}_{50}$ (increasing rate of desensitization or decreasing rate of recovery from desensitization) should be correlated with compensatory increases of $k_{\text {off }}$ (which would tend to increase $\mathrm{IC}_{50}$ ) and vice versa. We tested this prediction by measuring the correlation of $k_{\text {off }}$ and of each blocked arm desensitization rate that was allowed to vary (Table 4). We found that $k_{\mathrm{d} 1+}^{\prime}$ was positively correlated with $k_{\text {off }}(r=0.96 ; p=0.0006), k_{\mathrm{d} 2+}^{\prime}$ trended toward a positive correlation with $k_{\text {off }}(r=0.73 ; p=$ $0.06), k_{\mathrm{d} 2}^{\prime}$ - was negatively correlated with $k_{\text {off }}(r=-0.82 ; p=$ $0.02)$, and $k_{\mathrm{d} 2}^{\prime}$ trended toward a negative correlation with $k_{\text {off }}$ $(r=-0.59 ; p=0.16)$. These results are consistent with the expectation that, when a rate into or out of a desensitized state changed, a compensatory change in $k_{\text {off }}$ occurred to maintain appropriate memantine $\mathrm{IC}_{50}$. In most of the models used to measure the above correlations, multiple desensitization rates were allowed to vary; therefore, $k_{\text {off }}$ and individual desensitization rates were not always tightly correlated.

Our results using both models 1 and 2 support the conclusion that stabilization by memantine of desensitized states can explain memantine's preferential inhibition of responses activated by long glutamate applications. However, model 2 is more complex than model 1 and it is possible that a version of model 2 in which memantine affects gating rather than desensitization could provide equally good fits to experimental data. To examine this possibility, we fit to data a version of model 2 in which the blocked arm desensitization rates were fixed but the gating rates were allowed to vary. To provide a fair comparison with model $2 \mathrm{p}$, we left the same number of rate constants free (six) in the new model version (model $2 \mathrm{q})$ : all four gating rates $\left(k_{1+/-}^{\prime}\right.$ and $\left.k_{2+\prime-}^{\prime}\right)$, which replaced the four desensitization rates that were free in model $2 \mathrm{p}$, along with $k_{\text {off }}$ and $k_{\mathrm{a}-}^{\prime}$, which also were free in model 2 p. Despite having six free parameters, the percentage best fit achieved by model $2 \mathrm{q}$ was only $93.7 \%$ (Table 4 ). Model 2q performed similarly to (models 2c, 2d, 2f; Table 4) or worse than (model 2e) models with only two free parameters: $k_{\text {off }}$ and one desensitization rate. These results do not rule out the possibility that memantine may affect gating transitions. However, the performance of model $2 \mathrm{q}$ further supports the conclusion that stabilization of desensitized states is the predominant mechanism by which memantine preferentially inhibits GluN1/2A receptor responses activated by long glutamate applications.

We noted that the kinetics of channel blocker action are complex both in our models and in experimental data. Most relaxations during inhibition by memantine and recovery of inhibition are multiexponential in simulations by both models 1 and 2, as would be expected for such complex models. Similarly, experimental relaxations typically were multiexponential. Although not explored in detail in simulations performed here, the kinetics of response inhibition depended on agonist concentration (because $P_{\text {open }}$ depends on agonist concentration and the kinetics of response inhibition depend on $P_{\text {open }}$ ) and blocker concentration. Agonist concentration dependence of the kinetics of channel block can be seen in Figure 1 and was also observed in model simulations (data not shown). 
A

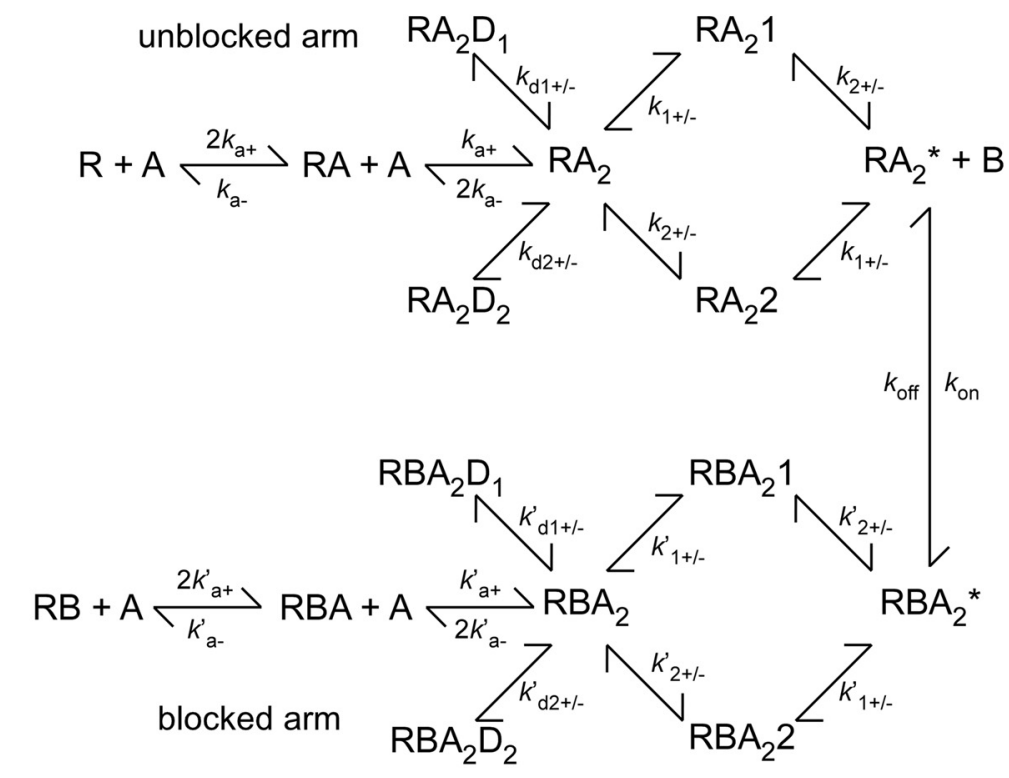

B
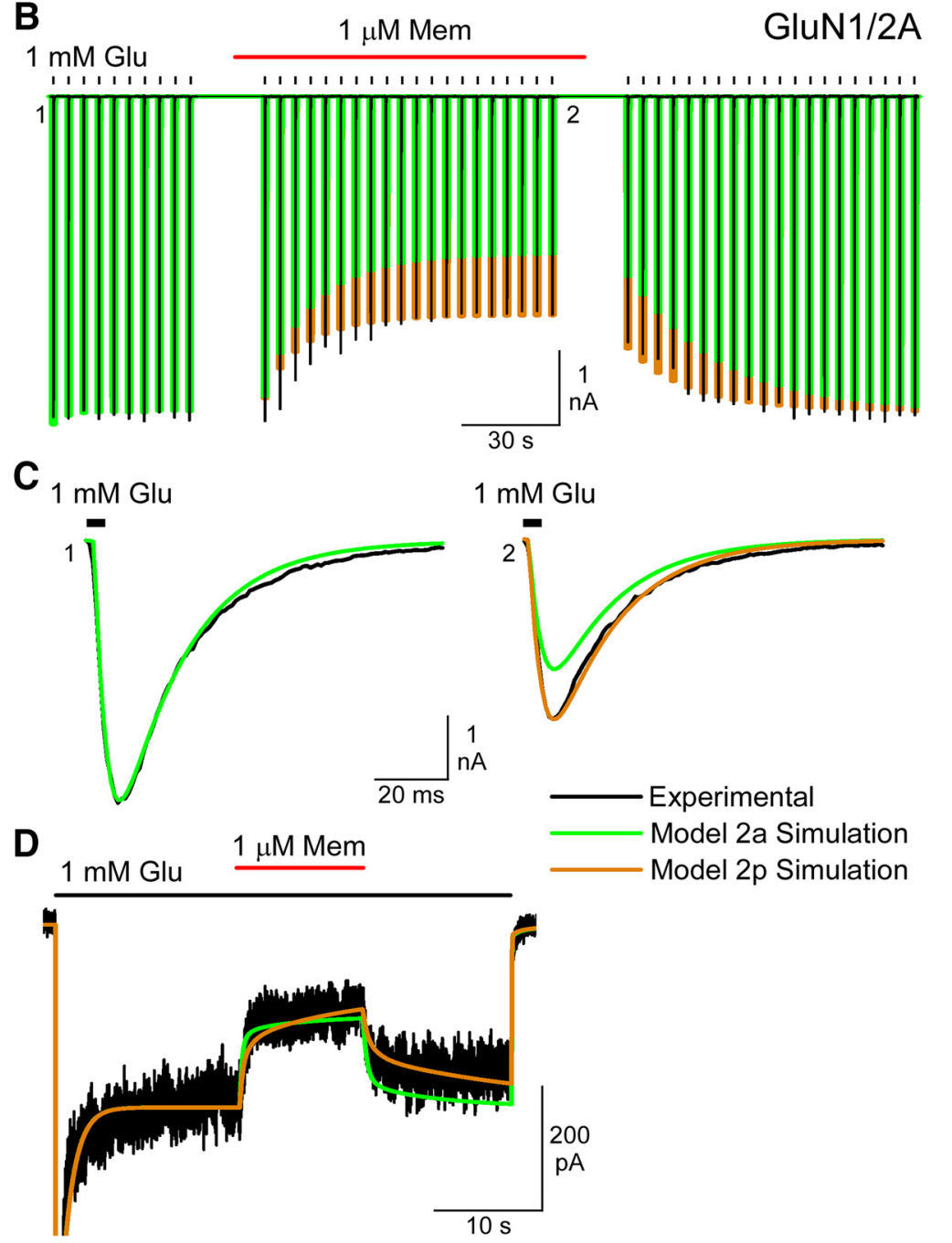

Figure 5. Model 2 simulations suggest that memantine increases occupancy of desensitized states of GluN1/2A receptors. $\boldsymbol{A}$, GluN1/2A receptor trapping block model (model 2) used for fitting to experimental recordings. $\boldsymbol{B}-\boldsymbol{D}$, Experimental recordings (black traces; plotted with thin black lines in $\boldsymbol{B}$ to improve trace visibility) of $G$ luN1/2A receptors activated by synaptic-like $(\boldsymbol{B}, \boldsymbol{C})$ or long $(\boldsymbol{D})$ applications of $1 \mathrm{~mm}$ glutamate in the absence or presence of memantine overlaid with simulations of model $2 a$
Memantine and ketamine differentially alter desensitization of NMDARs

Our modeling results suggest that, when memantine occupies the channel of GluN1/2A receptors, the rate of desensitization is increased and/or the rate of recovery from desensitization is decreased. We next designed an experimental protocol to test the hypothesis that memantine block reduces the rate of recovery from desensitization. We first used model $2 p$ to simulate the time course of recovery from desensitization in the absence (control) and presence of memantine. Model $2 \mathrm{p}$ predicts that the time course of recovery from desensitization, measured as described below, should be $\sim 3$-fold slower in $3 \mu \mathrm{M}$ memantine (a concentration at which memantine inhibits NMDAR-mediated responses by $\sim 70 \%$ ) than in 0 memantine (cf. model $2 \mathrm{p}$ memantine and model $2 \mathrm{p}$ control simulations in Fig. 6D). We then tested the model $2 \mathrm{p}$ prediction in cells expressing GluN1/2A receptors by measuring the time course of recovery from desensitization in control and in $3 \mu \mathrm{M}$ memantine.

To measure the time course of recovery from desensitization, we used the following protocol. We applied $1 \mathrm{~mm}$ glutamate for $30 \mathrm{~s}$ to GluN1/2A-expressing tsA201 cells held at $-65 \mathrm{mV}$ to allow receptors to reach a steady-state level of activation, washed with 0 glutamate for a variable time interval (interapplication interval), and then reapplied $1 \mathrm{~mm}$ glutamate for $30 \mathrm{~s}$ (Fig. $6 A, B$ ). The wash and glutamate reapplication were repeated with the interapplication interval varying from 0.2 to $200 \mathrm{~s}$. We measured the $I_{\text {peak }}$ after reapplication of glutamate and normalized it to the $I_{\text {peak }}$ after the longest interapplication interval of 200 s. A weighted time constant ( $\tau_{\mathrm{w}}$; see Materials and Methods) for recovery from desensitization was calculated based on a double exponential fit to the dependence of $I_{\text {peak }}$ on interapplication interval. This protocol for measuring the time course of recovery from desensitization was performed in control and in $3 \mu \mathrm{M}$ memantine. We found that $3 \mu \mathrm{M}$ memantine slowed recovery from desensitization sig-

(symmetric model; green traces) or model 2p (orange traces) Current traces and simulations in $\boldsymbol{C}$ show with an expanded time scale individual responses to synaptic-like applications of glutamate labeled 1 and 2 in $\boldsymbol{B}$. Model $2 \mathrm{a}$ and model $2 \mathrm{p}$ share the same unblocked arm rates and thus simulated responses that precede memantine application are identical. Time of application of glutamate is indicated by black bars above traces and application of memantine is indicated by red bars above traces. 
Table 4. Summary of blocked arm rates from Model 2 fits

\begin{tabular}{|c|c|c|c|c|c|c|c|c|c|}
\hline \multirow[b]{2}{*}{ Model 2 version } & \multirow[b]{2}{*}{ No. of free rates } & \multirow[b]{2}{*}{ SSE } & \multirow[b]{2}{*}{ Best fit } & \multicolumn{6}{|c|}{ Model 2A blocked arm rates } \\
\hline & & & & $k_{\mathrm{a}-}^{\prime}$ & $k_{\mathrm{d} 1+}^{\prime}$ & $k_{\mathrm{d} 1-}^{\prime}$ & $k_{\mathrm{d} 2+}^{\prime}$ & $k_{\mathrm{d} 2-}^{\prime}$ & $k_{\text {off }}$ \\
\hline Model 2a & 0 & $10,398,950$ & $0 \%$ & \multicolumn{5}{|c|}{ Fitted Model 2 blocked arm rates } & 30 \\
\hline Model 2b & 2 & $7,121,514$ & $83.4 \%$ & 167 & & & & & 29 \\
\hline Model $2 c$ & 2 & $6,844,055$ & $90.5 \%$ & & 8700 & & & & 204 \\
\hline Model 2d & 2 & $6,844,055$ & $90.5 \%$ & & & 0.06 & & & 78 \\
\hline Model $2 g$ & 3 & $6,826,384$ & $90.9 \%$ & 1263 & 8953 & & & & 224 \\
\hline Model $2 \mathrm{~h}$ & 3 & $6,515,829$ & $98.8 \%$ & 661 & & 0.06 & & & 70 \\
\hline Model 2i & 3 & $6,574,859$ & $97.3 \%$ & 1531 & & & 530 & & 111 \\
\hline Model 2j & 3 & $6,567,645$ & $97.5 \%$ & 307 & & & & 0.08 & 50 \\
\hline Model $2 \mathrm{k}$ & 3 & $6,499,084$ & $99.3 \%$ & & 187 & 0.12 & & & 90 \\
\hline Model 21 & 3 & $6,503,251$ & $99.2 \%$ & & & & 233 & 0.13 & 90 \\
\hline Model 2m & 4 & $6,489,427$ & $99.5 \%$ & 550 & 100 & 0.08 & & & 69 \\
\hline Model $2 q$ & 6 & $6,716,395$ & $93.7 \%$ & 110 & 265 & 253 & 96 & 31 & 37 \\
\hline
\end{tabular}

The indicated combinations of Model 2 blocked arm rates were allowed to vary during fits to experimental recordings. Final sums of squared error (SSEs) for the least squares fit are shown. Best fit was calculated as follows: (SSE Model $2 a-$ SSE Model $2 x) /(S S E$ Model $2 a-$ Model $2 p) * 100$, where Model $2 x$ is the Model 2 version identified in the first column. Model $2 a$ was the symmetric model in which no rates were allowed to vary. For Models $2 b-2 q$, only the rates that were allowed to vary during fitting of each model are shown. All rates not shown are identical to Model 2 unblocked arm rates (Table 5).

Table 5. Model 2 fits suggest that memantine affects NMDAR desensitization

\begin{tabular}{|c|c|c|c|c|}
\hline Rate constant & Units & $\begin{array}{l}\text { Model 2a } \\
\text { (symmetric) }\end{array}$ & $\begin{array}{l}\text { Model } 2 p \\
\text { (best fit) }\end{array}$ & $\begin{array}{l}\text { Fold } \\
\text { change }\end{array}$ \\
\hline \multicolumn{5}{|c|}{ Model 2 unblocked arm rates } \\
\hline$k_{\mathrm{a}+}$ & $\mu M^{-1} s^{-1}$ & 31.6 & 31.6 & - \\
\hline$k_{\mathrm{a}-}$ & $s^{-1}$ & 1010 & 1010 & - \\
\hline$k_{1+}^{a}$ & $s^{-1}$ & 2155 & 2155 & - \\
\hline$k_{1-}$ & $s^{-1}$ & 198 & 198 & - \\
\hline$k_{2+}$ & $s^{-1}$ & 109 & 109 & - \\
\hline$k_{2-}$ & $s^{-1}$ & 185 & 185 & - \\
\hline$k_{\mathrm{d} 1+}$ & $s^{-1}$ & 72.5 & 72.5 & - \\
\hline$k_{\mathrm{d} 1-}$ & $s^{-1}$ & 1.96 & 1.96 & - \\
\hline$k_{\mathrm{d} 2+}$ & $s^{-1}$ & 76.7 & 76.7 & - \\
\hline$k_{\mathrm{d} 2}-$ & $s^{-1}$ & 0.24 & 0.24 & - \\
\hline \multicolumn{5}{|c|}{ Model 2 blocked arm rates } \\
\hline$k_{\mathrm{a}+}^{\prime}$ & $\mu \mathrm{M}^{-1} \mathrm{~s}^{-1}$ & 31.6 & 31.6 & - \\
\hline$k_{\mathrm{a}-}^{\prime}$ & $s^{-1}$ & 1010 & $550^{a}$ & $\downarrow 1.8 \times$ \\
\hline$k_{1+}^{\prime}$ & $s^{-1}$ & 2155 & 2155 & - \\
\hline$k_{1-}^{\prime}$ & $s^{-1}$ & 198 & 198 & - \\
\hline$k_{2+}^{\prime}$ & $s^{-1}$ & 109 & 109 & - \\
\hline$k_{2-}^{\prime}$ & $s^{-1}$ & 185 & 185 & - \\
\hline$k_{\mathrm{d} 1+}^{\prime}$ & $s^{-1}$ & 72.5 & $142^{a}$ & $\uparrow 2 \times$ \\
\hline$k_{\mathrm{d} 1-}^{\prime}$ & $s^{-1}$ & 1.96 & $0.36^{a}$ & $\downarrow 5.4 \times$ \\
\hline$k_{\mathrm{d} 2+}^{\prime}$ & $s^{-1}$ & 76.7 & $85^{a}$ & $\uparrow 1.1 \times$ \\
\hline$k_{\mathrm{d} 2-}^{\prime}$ & $s^{-1}$ & 0.24 & $0.06^{a}$ & $\downarrow 4 \times$ \\
\hline$k_{\text {on }}$ & $\mu \mathrm{M}^{-1} \mathrm{~s}^{-1}$ & 30 & 30 & - \\
\hline$k_{\text {off }}$ & $s^{-1}$ & 30 & $71^{a}$ & $\uparrow 2.4 \times$ \\
\hline
\end{tabular}

Model 2 a represents the symmetric model with unblocked arm rates determined by fitting to data in the absence of memantine and all blocked arm rates fixed at the values of corresponding unblocked arm rates (see Materials and Methods). Model 2 a rates served as the initial rate values used during fitting of Model $2 p$ to experimental recordings (Fig. $5 B-D$ ). Changes in fitted rates that yielded the best fit are displayed as increases (up arrows) or decreases (down arrows) followed by the fold change.

${ }^{a}$ Model 2 blocked arm rates that were allowed to vary during fits to experimental recordings for Model $2 p$, which was the model that achieved the best fit (Table 4). All other rates were fixed during fits. nificantly (control, $\tau_{\mathrm{w}}=5.46 \pm 1.71 \mathrm{~s}$; memantine, $\tau_{\mathrm{w}}=47.2 \pm$ $8.50 \mathrm{~s} ; p<0.0001$, one-way ANOVA with Tukey's post hoc analysis; Fig. $6 B, E, J)$. Our experimental results display even greater slowing of recovery from desensitization than predicted by model $2 \mathrm{p}$ (model $2 \mathrm{p}$ control, $\tau_{\mathrm{w}}=4.67 \mathrm{~s}$; model $2 \mathrm{p}$ memantine, $\tau_{\mathrm{w}}=$ $13.1 \mathrm{~s}$; Fig. $6 D$ ). In contrast to model $2 \mathrm{p}$, model $2 \mathrm{q}$ (in which gating rates rather than desensitization rates are allowed to vary) does not predict any slowing of recovery from desensitization $\left(\tau_{\mathrm{w}}=4.03 \mathrm{~s}\right.$; data not shown). Therefore, our modeling and experimental results both are consistent with the conclusion that memantine stabilizes one or more GluN1/2A receptor desensitized states, at least in part by slowing the rate of recovery from desensitization.

Next, we compared experimentally the effects of memantine and ketamine on recovery from desensitization of GluN1/2A and GluN1/2B receptors. Using the protocol described above, we measured the time course of recovery from desensitization in control and in $3 \mu \mathrm{M}$ memantine or $1.5 \mu \mathrm{M}$ ketamine; the concentration of ketamine was chosen so both drugs were applied at similar concentrations relative to their $\mathrm{IC}_{50} \mathrm{~s}$.

For GluN1/2A receptors, we found that, unlike memantine, ketamine had no significant effect on the time course of recovery from desensitization ( $p=0.73$, one-way ANOVA with Tukey's post hoc analysis; Fig. 6C,E,J). The normalized $I_{\text {peak }}$ for memantine was significantly less than for ketamine and for control at each interapplication interval except for $200 \mathrm{~s}$, whereas normalized $I_{\text {peak }}$ for ketamine and control did not differ significantly at any interapplication interval (Fig. 6E). In addition, recovery from desensitization in ketamine was well fit by a single exponential function, whereas a double exponential function was needed for memantine. This suggests that memantine and ketamine have distinct effects on GluN1/2A receptor desensitization.

For GluN1/2B receptors, we found that memantine had no significant effect on recovery from desensitization $(p=0.14$, one-way ANOVA with Tukey's post hoc analysis; Fig. $6 G, I, J)$. In contrast, recovery from desensitization of GluN1/2B receptors in 
A

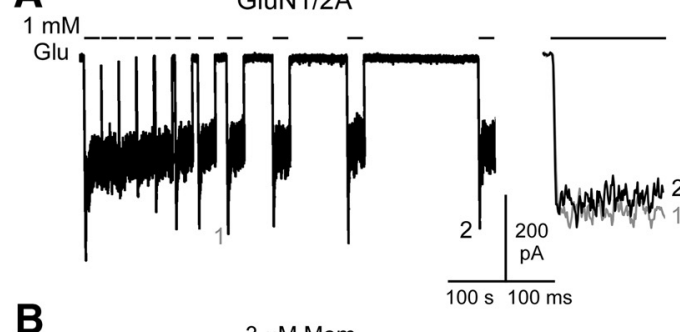

B

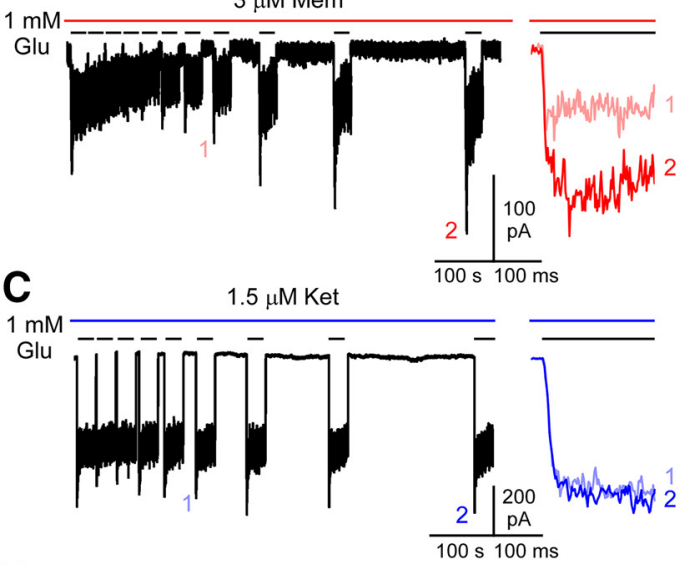

D

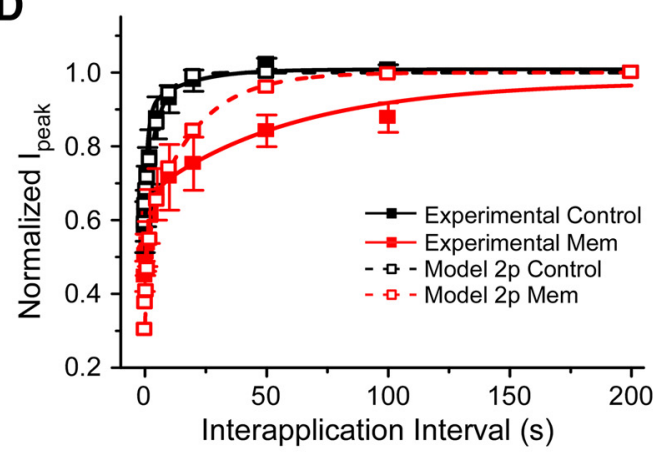

E

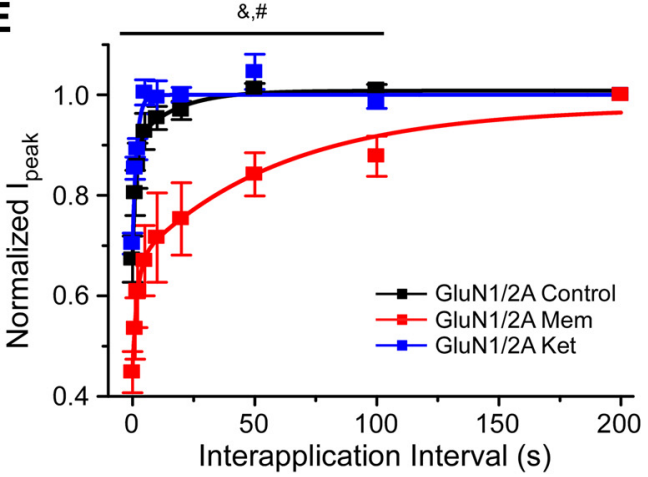

F

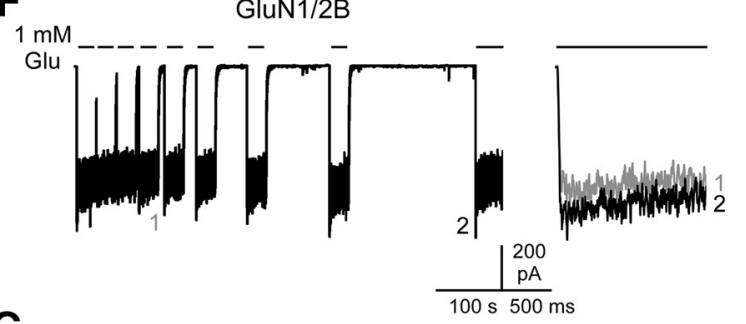

G

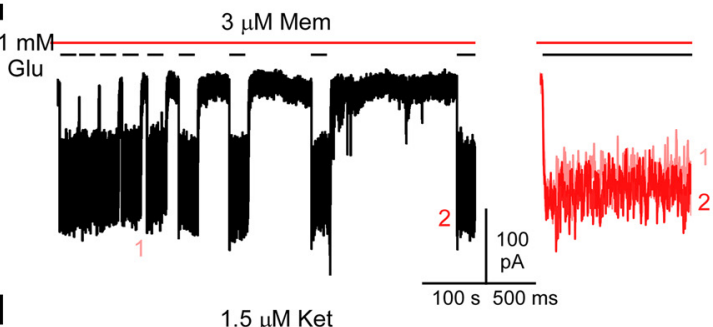

H

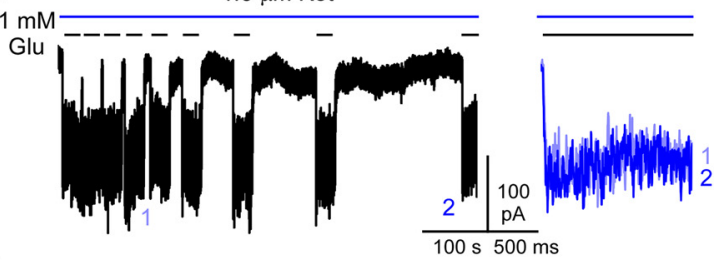

I

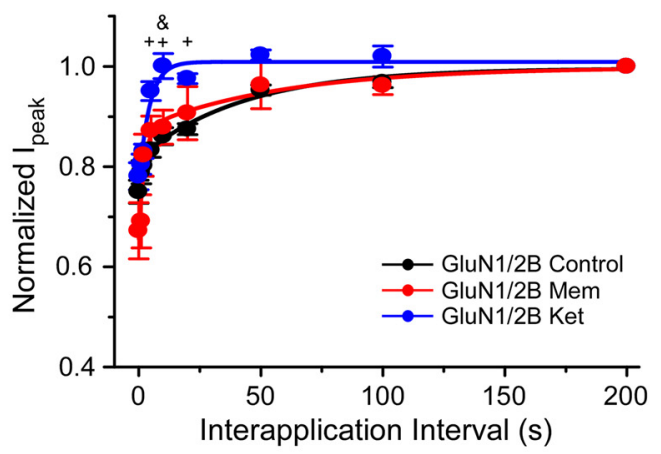

$\mathbf{J}$

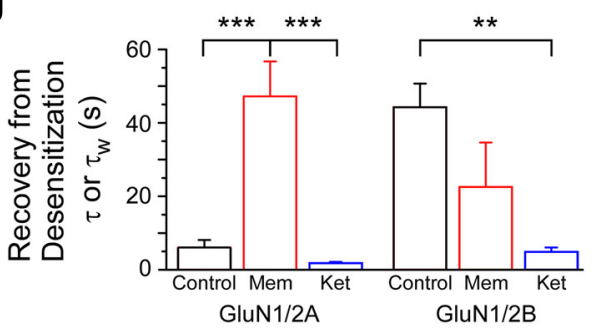

Figure 6. Memantine and ketamine differentially alter NMDAR desensitization. $\boldsymbol{A}-\boldsymbol{C}$, Representative current traces of GluN1/2A receptors activated by $1 \mathrm{~mm}$ glutamate during the recovery from desensitization protocol in control $(\boldsymbol{A})$, in the presence of $3 \mu \mathrm{m}$ memantine $(\boldsymbol{B})$, and in the presence of $1.5 \mu \mathrm{m}$ ketamine $(\boldsymbol{C})$. Insets at right show current responses to glutamate application with an expanded time scale at the two interapplication intervals labeled 1 (20 sinterval; gray, pink, and light blue traces) and 2 (200 sinterval; black, red, and blue traces) in control ( $\boldsymbol{A}$ ), memantine $(\boldsymbol{B})$, and ketamine (C). Bars above traces indicate time of application of glutamate (black bars), memantine (red bars), and ketamine (blue bars). D, Summary of GluN1/2A receptor recovery from desensitization results in control (black) and in memantine (red) for experiments and for simulations. Closed squares display mean $I_{\text {peak }}$ normalized to $I_{\text {peak }}$ after a 200 s interapplication interval. 0 pen squares display the normalized $I_{\text {peak }}$ simulated by model $2 \mathrm{p}$ in control and in memantine. Single or double exponential fits to the time course of recovery from desensitization are shown with solid lines (fits to data) and dashed lines (fits to simulations). E, Summary of GluN1/2A receptor recovery from desensitization results in control (black), memantine (red), and ketamine (blue) experiments. Closed symbols display mean normalized $I_{\text {peak }}$. Lines show single or double exponential fits to the time course of recovery from desensitization. Data for inhibition by memantine from $D$ are replotted here. Mean $I_{\text {peak }}$ at each interapplication interval was compared by one-way ANOVA with Tukey's post hoc analysis. \#p $<0.05$ between control and memantine; $\& p<0.05$ between memantine and ketamine. Memantine was significantly different from control and ketamine at each interapplication interval except for $200 \mathrm{~s}$ (to which all $I_{\text {peak }}$ values were normalized). $\boldsymbol{F}-\boldsymbol{H}$, Representative current traces as in $\boldsymbol{A}$-C except for GluN1/2B receptors in control $(\boldsymbol{F}), 3 \mu \mathrm{m}$ memantine $(\boldsymbol{G})$, and $1.5 \mu \mathrm{m}$ ketamine $(\boldsymbol{H})$. Insets at right are current traces at expanded time scales at interapplication intervals labeled 1 ( 5 s interval; gray, pink, and light blue traces) and 2 (200 s interval; black, red, and blue traces). $I$, As in $\boldsymbol{E}$, except for GluN1/2B receptors. Mean $I_{\text {peak }}$ at each interapplication interval was compared by one-way ANOVA with Tukey's post hoc analysis. $+p<0.05$ between control and ketamine; $\& p<0.05$ between memantine and ketamine. J, Mean $\tau$ or $\tau_{w}$ from fits of the time course of recovery from desensitization. ${ }^{\star \star} p<0.01$ and ${ }^{\star \star \star} p<0.001$ by one-way ANOVA with Tukey's post hoc analysis. $n=5-11$ cells in each group. 
ketamine was $\sim 3.5$-fold faster than in control and was well fit by a single exponential ( $p=0.005$, one-way ANOVA with Tukey's post hoc analysis; Fig. $6 H-J)$. The normalized $I_{\text {peak }}$ for memantine was not significantly different from control at any interapplication interval, but was significantly less than the normalized $I_{\text {peak }}$ for ketamine at $10 \mathrm{~s}$ (Fig. 6I, "\&"). The normalized $I_{\text {peak }}$ for ketamine was significantly greater than for control at several interapplication intervals (Fig. 6I, “+”). These results suggest that ketamine, but not memantine, accelerates recovery from desensitization of GluN1/2B receptors.

If ketamine accelerates recovery from desensitization of GluN1/2B receptors but affects no other transition rates, a rebound current might be expected after washout of a saturating ketamine concentration in the continuous presence of glutamate (e.g., using the protocol shown in Fig. 1D). However, we did not observe rebound currents. Rebound currents in our experiments may have been too small to measure because desensitization develops with a $\tau$ of $\sim 1.5 \mathrm{~s}$, whereas ketamine unbinds with a $\tau$ of $\sim 3.5 \mathrm{~s}$ and GluN1/2B receptors only desensitize $\sim 20 \%$, making the maximal rebound current amplitude relatively small.

\section{Memantine stabilizes a $\mathrm{Ca}^{2+}$-dependent desensitized state of GluN1/2A receptors}

Next, we investigated whether memantine affects a specific type of NMDAR desensitization. GluN1/2A receptor-mediated currents typically decay slowly during prolonged exposure to a constant concentration of agonists via multiple mechanisms that have been referred to as desensitization or inactivation (Traynelis et al., 2010). We will use desensitization to refer generally to decreases in current in the continuous presence of a constant agonist concentration. There are at least three separable types of NMDAR desensitization (Traynelis et al., 2010): (1) glycinedependent desensitization, which involves a glutamate-induced decrease of glycine affinity that, due to our use of a saturating glycine concentration, we did not observe; (2) $\mathrm{Ca}^{2+}$-dependent desensitization, which is thought to result from NMDAR-mediated increases in intracellular $\mathrm{Ca}^{2+}$, thereby activating signaling pathways that act on the C-terminal domains (CTDs) of GluN1/2A receptors; and (3) glycine- and $\mathrm{Ca}^{2+}$-independent desensitization. We next tested whether memantine stabilizes a $\mathrm{Ca}^{2+}$-dependent desensitized state. We measured the time course of recovery from desensitization in control and in $3 \mu \mathrm{M}$ memantine using the following low- $\mathrm{Ca}^{2+}$ condition: extracellular solution was modified by reducing external $\mathrm{Ca}^{2+}\left(\mathrm{Ca}_{\mathrm{o}}^{2+}\right)$ concentration to $0.1 \mathrm{~mm}$, a $\mathrm{Ca}_{\mathrm{o}}^{2+}$ concentration that does not support $\mathrm{Ca}^{2+}$-dependent desensitization (Legendre et al., 1993), and intracellular solution, which contained $10 \mathrm{~mm}$ internal BAPTA $\left(\right.$ BAPTA $\left._{\mathrm{i}}\right)$, which was not modified. We found that, in the absence of memantine, recovery from desensitization was slightly, but not significantly, faster in low- $\mathrm{Ca}^{2+}$ conditions $\left(\tau_{\mathrm{w}}=1.93 \pm 0.25 \mathrm{~s} ; p=0.32\right.$, one-way ANOVA with Tukey's post hoc analysis) than in normal $\mathrm{Ca}^{2+}$ conditions. In contrast to our results in normal $\mathrm{Ca}^{2+}$ conditions, addition of $3 \mu \mathrm{M}$ memantine in low- $\mathrm{Ca}^{2+}$ conditions did not affect the time course of recovery from desensitization $\left(\tau_{\mathrm{w}}=\right.$ $1.28 \pm 0.35 \mathrm{~s} ; p=0.98$, one-way ANOVA with Tukey's post hoc analysis; Fig. $7 A$ ). Our results suggest that memantine specifically slows recovery from a $\mathrm{Ca}^{2+}$-dependent desensitized state.

The results of our kinetic modeling and Figure $7 A$ suggest that memantine inhibits GluN1/2A receptors more effectively during long than during synaptic-like glutamate applications by stabilizing a $\mathrm{Ca}^{2+}$-dependent desensitized state. If this conclusion is correct, then in the low extracellular $\mathrm{Ca}^{2+}$ concentration used for Figure $7 A$, memantine inhibition of GluN1/2A receptors during long and synaptic-like glutamate applications should be similar. We tested this prediction using the same experimental protocol used earlier to compare memantine inhibition of long and synapticlike glutamate applications (Fig. $3 A$ ), except in low (0.1 mM) extracellular $\mathrm{Ca}^{2+}$. Consistent with our prediction, we found that the difference in memantine inhibition of GluN1/2A receptors between long and synaptic-like glutamate applications in normal $\mathrm{Ca}^{2+}$ conditions was abolished in low-Ca ${ }^{2+}$ conditions $\left(I_{\mathrm{drug}} /\right.$ $I_{\text {control }}$ : synaptic-like, $0.60 \pm 0.01$; long, $0.67 \pm 0.02 ; p=0.14$; two-way repeated-measures ANOVA with Bonferroni correction; $n=4$; Fig. $7 B$ ). Furthermore, memantine inhibition of GluN1/2A receptors during synaptic-like glutamate applications was indistinguishable between normal $\mathrm{Ca}^{2+}$ and low-Ca ${ }^{2+}$ conditions $(p=0.14$; two-way repeated-measures ANOVA with Bonferroni correction), whereas inhibition during long glutamate applications was significantly greater in normal $\mathrm{Ca}^{2+}$ than in low- $\mathrm{Ca}^{2+}$ conditions $(p=0.0005$; two-way repeated-measures ANOVA with Bonferroni correction). These data support the conclusion that memantine inhibits GluN1/2A receptor responses activated by long glutamate applications preferentially by increasing occupancy of $\mathrm{Ca}^{2+}$-dependent desensitized states.

If memantine binding slows recovery from a $\mathrm{Ca}^{2+}$-dependent desensitized state and, as a result, increases desensitized state occupancy, then memantine $\mathrm{IC}_{50}$ should be $\mathrm{Ca}^{2+}$ sensitive. To test this prediction, we compared the memantine $\mathrm{IC}_{50}$ that we measured in our normal $\mathrm{Ca}^{2+}$ recording condition $\left(1 \mathrm{mM} \mathrm{Ca}_{\mathrm{o}}^{2+} ; 10\right.$ mM BAPTA $A_{i}$; Fig. 1) and memantine $\mathrm{IC}_{50}$ s recorded in two additional recording conditions (Fig. 7C,D): (1) the low-Ca ${ }^{2+}$ condition used above $\left(0.1 \mathrm{mM} \mathrm{Ca}_{\mathrm{o}}^{2+} ; 10 \mathrm{mM} \mathrm{BAPTA}_{\mathrm{i}}\right)$ to minimize increases of intracellular $\mathrm{Ca}^{2+}$; and (2) high- $\mathrm{Ca}^{2+}$ condition $\left(1 \mathrm{mM} \mathrm{Ca}_{\mathrm{o}}^{2+} ; 1 \mathrm{mM} \mathrm{EGTA}_{\mathrm{i}}\right.$ ) to enhance increases of intracellular $\mathrm{Ca}^{2+}$. Memantine $\mathrm{IC}_{50}$ s differed significantly in all three $\mathrm{Ca}^{2+}$ conditions. Consistent with our finding that memantine stabilizes a $\mathrm{Ca}^{2+}$-dependent desensitized state, memantine $\mathrm{IC}_{50}$ was highest in the low- $\mathrm{Ca}^{2+}$ condition $(2.41 \pm 0.12 \mu \mathrm{M})$, intermediate in the normal $\mathrm{Ca}^{2+}$ condition $(1.82 \pm 0.06 \mu \mathrm{M}$, Table 1$)$, and lowest in the high- $\mathrm{Ca}^{2+}$ condition $(1.22 \pm 0.06 \mu \mathrm{M}$; low vs normal $\mathrm{Ca}^{2+}, p=0.004$; low- vs high-Ca ${ }^{2+}, p<0.0001$; normal vs high-Ca ${ }^{2+}, p=0.002$; one-way ANOVA with Tukey's post hoc analysis). Note that memantine $\mathrm{IC}_{50} \mathrm{~s}$ were significantly different in two conditions (normal and high- $\mathrm{Ca}^{2+}$ ) that were differentiated only by the intracellular $\mathrm{Ca}^{2+}$ buffer used. The $\mathrm{Ca}^{2+}$ dependence of memantine $\mathrm{IC}_{50}$ therefore is likely to be due to intracellular actions of $\mathrm{Ca}^{2+}$ rather than a direct effect of extracellular $\mathrm{Ca}^{2+}$ on the NMDAR channel (Ascher and Nowak, 1988; Maki and Popescu, 2014). The memantine $\mathrm{IC}_{50}$ in low-Ca ${ }^{2+}$ conditions is similar to the $K_{\mathrm{d}}\left(K_{\mathrm{d}}=k_{\text {off }} / k_{\text {on }}\right)$ predicted by model $2 \mathrm{p}$ (2.37 $\mu \mathrm{M}$; Table 5). Because $K_{\mathrm{d}}=\mathrm{IC}_{50}$ in a symmetric model (Johnson and Qian, 2002), the similarity of $K_{\mathrm{d}}$ and $\mathrm{IC}_{50}$ in low$\mathrm{Ca}^{2+}$ conditions suggests that memantine block of GluN1/2A receptor channels alters transition rates substantially only when $\mathrm{Ca}^{2+}$-dependent desensitization can occur.

To determine whether memantine inhibition of native neuronal NMDARs also is $\mathrm{Ca}^{2+}$ dependent, we examined the effect of memantine on evoked synaptic responses in acute brain slices. We chose to record postsynaptic responses of pyramidal neurons in adult mouse PFC slices, where most synaptic NMDARs contain the GluN2A subunit (Paoletti et al., 2013). If memantine binding increases desensitized state occupancy, then strongly activated synaptic NMDARs should exhibit greater memantine inhibition in high-Ca ${ }^{2+}$ conditions (for slice experiments, $2 \mathrm{mM}$ $\mathrm{Ca}_{\mathrm{o}}^{2+}$ and no $\mathrm{Ca}^{2+}$ chelators in the intracellular solution) than in low- $\mathrm{Ca}^{2+}$ conditions (for slice experiments, $1 \mathrm{mM} \mathrm{Ca}_{\mathrm{o}}^{2+}$ and 10 
A

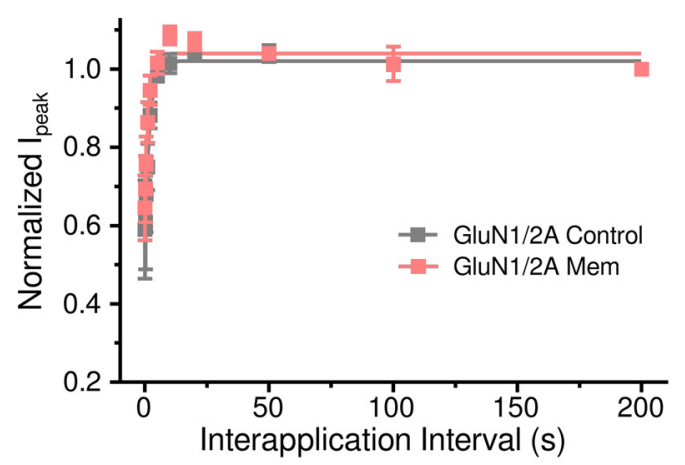

C

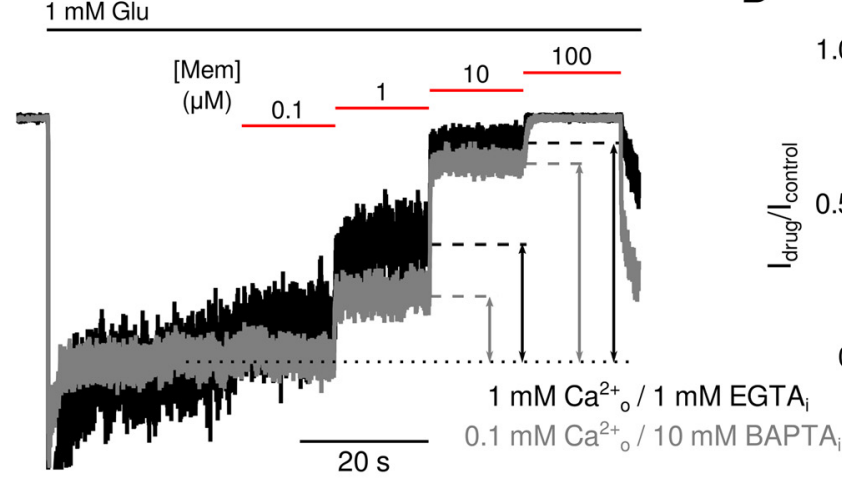

E

$2 \mathrm{mM} \mathrm{Ca}^{2+}{ }_{0} / 0 \mathrm{BAPTA}_{\mathrm{i}}$

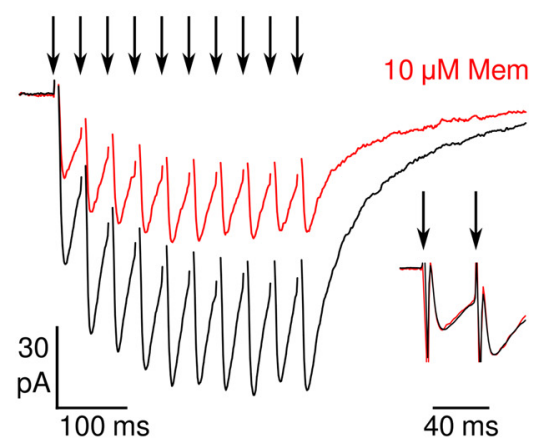

F

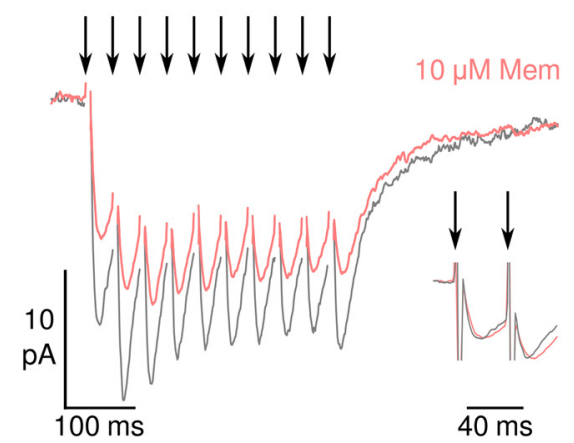

B

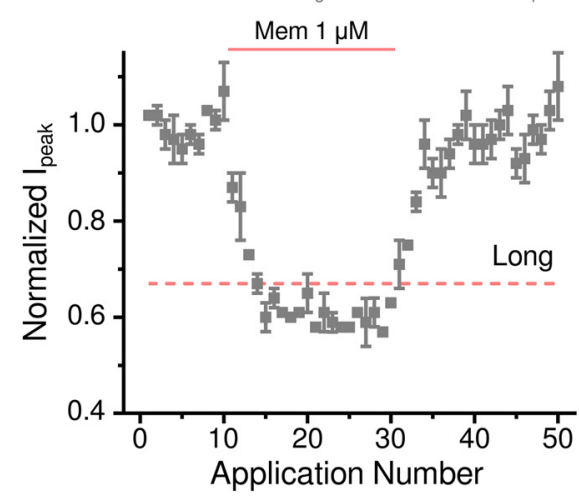

D

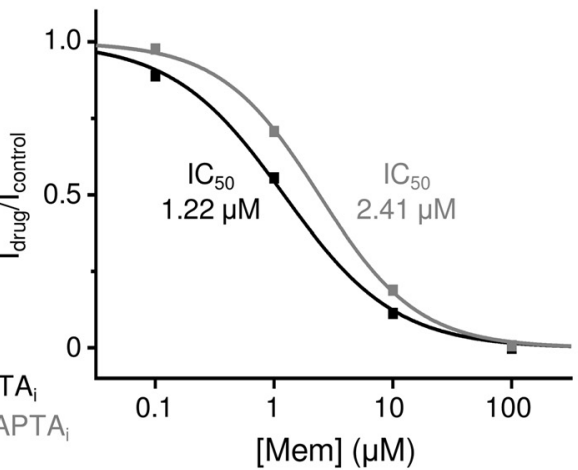

G
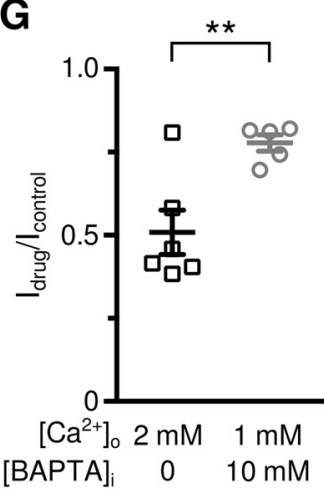

Figure 7. $\quad \mathrm{Ca}^{2+}$ dependence of memantine inhibition of GluN1/2A and native synaptic NMDARs. $A$, Recovery from desensitization protocol was performed using GluN1/2A receptors activated by $1 \mathrm{~mm}$ glutamate in $0.1 \mathrm{~mm} \mathrm{Ca}_{0}^{2+}$. Closed squares display mean $I_{\text {peak }}$ of GluN1/2A receptors normalized to $I_{\text {peak }}$ after a 200 s interapplication interval in control (gray) and in $3 \mu \mathrm{m} \mathrm{memantine} \mathrm{(red).}$ Single exponential fits to the time course of recovery from desensitization are shown with solid lines. B, Plot of mean $I_{\text {peak }}$ (gray symbols) during synaptic-like glutamate applications normalized to the average of the $I_{\text {peak }}$ in response to the first 10 synaptic-like glutamate applications. Pink dashed line indicates mean normalized steady-state current in memantine during long glutamate applications. The protocol was similar to the protocol used in Figure $3 \mathrm{~A}$ except the extracellular $\mathrm{Ca}^{2+}$ concentration was lowered to $0.1 \mathrm{~mm} . n=4$ cells. $C$, Representative current traces of GluN1/2A

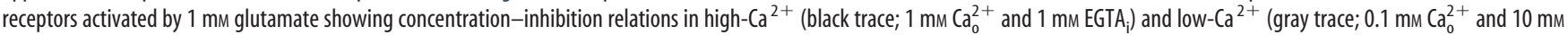
$\left.B A P T A_{i}\right)$ conditions. Traces are scaled to the difference between baseline current preceding glutamate application and mean current preceding memantine application. Bottom dotted line shows mean current preceding memantine application in both conditions, which are equal because of scaling. Mean current at the end of 1 and $10 \mu \mathrm{m}$ memantine applications is shown with black dashed lines (high- $\mathrm{Ca}^{2+}$ ) and with gray dashed lines (low- $\mathrm{Ca}^{2+}$ ). Time of application of glutamate is shown by black bar above traces. $\boldsymbol{D}$, Mean memantine concentration-inhibition relations for GluN1/2A receptors in high- $\mathrm{Ca}^{2+}$ (black squares and line) and low-Ca ${ }^{2+}$ (gray squares and line) conditions. Error bars are smaller than symbols. $\boldsymbol{E}, \boldsymbol{F}$, Representative averaged current traces showing NMDAR-EPSCs recorded from layer II/III pyramidal neurons in control (black and gray traces) and in $10 \mu$ memantine (red and pink traces) with high- $\mathrm{Ca}^{2+}\left(\boldsymbol{E}_{;} 2 \mathrm{~mm}_{\mathrm{Ca}} \mathrm{Ca}_{0}^{2+}\right.$ and $0 \mathrm{BAPTA}_{j} ;$ black traces) and low- $\mathrm{Ca}^{2+}\left(\boldsymbol{F} ; 1 \mathrm{~mm} \mathrm{Ca}{ }_{0}^{2+}\right.$ and $10 \mathrm{~mm} \mathrm{BAPTA}$; gray traces) conditions. NMDAR-EPSCs were evoked by trains of 10 extracellular stimuli (arrowheads) at $25 \mathrm{~Hz}$ with a 10 s intertrain interval. Insets at right show the first two NMDAR-EPSCs in the train, which were used for measuring PPR. Memantine traces in the inset are scaled to the amplitude of the first control response. PPR: High-Ca ${ }^{2+}$ control, $1.36 \pm 0.08$; high- $\mathrm{Ca}^{2+}$ memantine, $1.31 \pm 0.10 ; \mathrm{low}_{-} \mathrm{Ca}^{2+}$ control, $1.13 \pm 0.14 ; \mathrm{low}-\mathrm{Ca}^{2+}$ memantine, $1.16 \pm 0.16 .6$, Mean $I_{\text {drug }} / I_{\text {control }}$ for the response to the $10^{\text {th }}$ stimulus in 10 $\mu \mathrm{m}$ memantine with high-Ca ${ }^{2+}$ and low-Ca ${ }^{2+}$ conditions. ${ }^{\star \star} p=0.007$ by Student's $t$ test. $n=5-6$ cells in each group.

mM BAPTA $\left.{ }_{\mathrm{i}}\right)$. Although the high and low- $\mathrm{Ca}^{2+}$ conditions used in slice and tsA201 cell experiments necessarily differ (e.g., the lower $\mathrm{Ca}_{\mathrm{o}}^{2+}$ concentration used in slice experiments is relatively high to maintain synaptic transmission), in both preparations the two con- ditions compared should result in considerably different NMDARmediated increases of intracellular $\mathrm{Ca}^{2+}$ concentration.

We evoked NMDAR-EPSCs in layer II/III PFC pyramidal cells with trains of 10 extracellular stimuli at $25 \mathrm{~Hz}$ repeated every $10 \mathrm{~s}$ 
in NBQX to block AMPA and kainate receptor-mediated currents, and gabazine to block $\mathrm{GABA}_{\mathrm{A}}$ receptor-mediated currents. We also lowered $\mathrm{Mg}^{2+}$ to $0.5 \mathrm{~mm}$ in our ACSF to enhance NMDAR-EPSC amplitude, and thus $\mathrm{Ca}^{2+}$ influx and $\mathrm{Ca}^{2+}$ dependent desensitization. We assessed the effects of memantine inhibition on the amplitude of the $10^{\text {th }}$ response to maximize $\mathrm{Ca}^{2+}$-dependent desensitization. Strikingly, and consistent with our results in tsA201 cells, we found that inhibition by $10 \mu \mathrm{M}$ memantine was significantly greater in high- $\mathrm{Ca}^{2+}$ conditions than in low- $\mathrm{Ca}^{2+}$ conditions $(p=0.0068$; Student's $t$ test; Fig. $7 E-G)$. Therefore, also in native synaptic NMDARs, our data support the hypothesis that memantine inhibition depends in part on increasing the occupancy of a $\mathrm{Ca}^{2+}$-dependent desensitized state. Furthermore, our data support the hypothesis that memantine inhibition depends on the intensity of activation rather than exclusively on receptor location.

A potential concern is that our measurements of memantine inhibition of postsynaptic responses may have been contaminated by memantine inhibition of presynaptic NMDARs, which have been reported to modulate glutamate release (Corlew et al., 2008; but see Christie and Jahr, 2009). To assess possible presynaptic effects of memantine, we quantified the PPR using the first two NMDAR-EPSCs in response to stimulus trains before and during memantine application. We found that memantine did not affect PPR in either low- or high- $\mathrm{Ca}^{2+}$ conditions $(p>0.5$; one-way ANOVA with Tukey's post hoc analysis; Fig. $7 E, F)$. Although we cannot exclude a presynaptic action of memantine, our results suggest that memantine did not affect presynaptic release substantially under our recording conditions. Therefore, the difference between memantine inhibition in low- and high$\mathrm{Ca}^{2+}$ conditions is likely to be due predominantly to differential effects of memantine on postsynaptic NMDARs.

\section{Discussion}

Some of the differences in the clinical profiles of memantine and ketamine have been proposed to stem from the drugs inhibiting overlapping but distinct NMDAR subpopulations. Here, we uncovered differences in the mechanisms by which memantine and ketamine inhibit NMDARs that may underlie their ability to act on distinct receptor populations. We investigated whether inhibition by memantine and ketamine depended on three characteristics likely to vary between synaptic and extrasynaptic compartments: NMDAR subtype, glutamate concentration activating receptors, and duration for which receptors are exposed to glutamate. We found that inhibition by both memantine and ketamine depended on the duration of glutamate exposure in an NMDAR-subtype-dependent manner. Kinetic modeling suggested that the dependence of memantine inhibition on the duration of glutamate application results from memantine increasing the occupancy of NMDAR desensitized states. Our kinetic models guided design of experiments to examine effects of channel blockers on NMDAR desensitization. We found that memantine (but not ketamine) binding slows recovery from a Ca ${ }^{2+}$ dependent desensitized state of GluN1/2A receptors, whereas ketamine (but not memantine) binding accelerates recovery from GluN1/2B receptor desensitization. Consistent with memantine's ability to slow recovery of GluN1/2A receptors from $\mathrm{Ca}^{2+}$-dependent desensitization, we found that memantine inhibits GluN1/2A receptors with lower potency under conditions designed to minimize $\mathrm{Ca}_{\mathrm{i}}^{2+}$ concentration increases. We then used PFC brain slices to determine whether our results from a heterologous expression system also apply to native NMDARs. We found that pyramidal neuron postsynaptic NMDARs, most of which contain the GluN2A subunit, are less effectively inhibited by memantine under conditions designed to minimize $\mathrm{Ca}_{\mathrm{i}}^{2+}$ concentration increases. Our data support the conclusion that intracellular $\mathrm{Ca}^{2+}$ enhances memantine inhibition of both recombinant GluN1/2A receptors and native synaptic GluN2Asubunit-containing receptors.

Additional variables may affect memantine and ketamine inhibition of native NMDARs. We did not investigate many NMDAR subtypes, including triheteromeric NMDARs of known composition. Triheteromeric NMDARs may make up a majority of synaptic and extrasynaptic receptors (Paoletti et al., 2013). Although methods have been developed recently to study triheteromeric NMDARs in isolation (Hansen et al., 2014; Stroebel et al., 2014), these approaches involve modification of the NMDAR CTD, which may affect $\mathrm{Ca}^{2+}$-dependent desensitization. However, the difference between memantine inhibition of native synaptic NMDARs in low- and high- $\mathrm{Ca}^{2+}$ conditions suggests that GluN2A-containing triheteromeric receptors may also exhibit $\mathrm{Ca}^{2+}$-dependent memantine inhibition. We also did not investigate how $\mathrm{Mg}^{2+}$ may affect the ability of memantine or ketamine to alter desensitization. $\mathrm{Mg}^{2+}$ competes with memantine and ketamine for binding to NMDARs, thus lowering each drug's potency (Kotermanski and Johnson, 2009). Interestingly, inclusion of extracellular $\mathrm{Mg}^{2+}$ reveals differential inhibition by memantine and ketamine of spontaneous EPSCs (i.e., activation of synaptic NMDARs; Gideons et al., 2014).

The hypothesis that memantine inhibits extrasynaptic NMDARs more potently than synaptic NMDARs has been supported by multiple groups (Léveillé et al., 2008; Xia et al., 2010; Wild et al., 2013; Wu and Johnson, 2015). Despite the modest selectivity for extrasynaptic NMDARs that has been reported (twofold to fivefold over synaptic NMDARs), memantine is increasingly used as a tool to inhibit extrasynaptic NMDARs selectively (Kaufman et al., 2012; Dau et al., 2014; Riebe et al., 2016). However, our data argue that memantine is not selective specifically for synaptic or extrasynaptic NMDARs; instead, memantine inhibition depends upon $\mathrm{Ca}_{\mathrm{i}}^{2+}$ concentration and thus on the intensity of NMDAR activation, as well as on NMDAR subtype. Although GluN2A and GluN2B subunits appear to be segregated partially into synaptic and extrasynaptic compartments (Tovar and Westbrook, 1999; Groc et al., 2006; Papouin et al., 2012), this segregation is incomplete (Thomas et al., 2006b; Harris and Pettit, 2008; Petralia et al., 2010). Therefore, memantine inhibition does not depend principally on the NMDAR subcellular location, but rather on the likelihood of an NMDAR reaching a $\mathrm{Ca}^{2+}$-dependent desensitized state (e.g., during prolonged exposure to a high glutamate concentration). Memantine may appear to inhibit extrasynaptic receptors preferentially because extrasynaptic responses typically are activated by long-duration agonist application, a procedure more likely than synaptic activation to drive GluN2A-containing NMDARs into $\mathrm{Ca}^{2+}$-dependent desensitized states. Consistent with this idea, we demonstrate that memantine inhibition of synaptic NMDARs activated by trains of stimuli is sensitive to $\mathrm{Ca}^{2+}$.

In contrast to our findings, Emnett et al. (2013) found that memantine and ketamine act indistinguishably at synaptic and extrasynaptic NMDARs in cultured hippocampal neurons, although direct comparisons of inhibition of synaptic and extrasynaptic NMDARs were not made. Furthermore, similar inhibition of steady-state NMDAR currents by $2 \mu \mathrm{M}$ memantine was observed in 0.25 and $2 \mathrm{mM} \mathrm{Ca}^{2+}$. However, because relatively young cultured neurons (cultures from postnatal day $1-3$ rats at $5-10 \mathrm{~d}$ in vitro) were used, GluN2B-containing NMDARs may have pre- 
dominated. Our results suggest that only memantine inhibition of GluN2A-containing NMDARs exhibit $\mathrm{Ca}^{2+}$ dependence.

Our results suggest that the dependence of inhibition by both memantine and ketamine on duration of glutamate exposure is related to their effects on NMDAR desensitization. Memantine inhibits GluN1/2A (but not GluN1/2B) receptors more effectively during long than brief exposures to glutamate; memantine also slows recovery from GluN1/2A (but not GluN1/2B) receptor desensitization. Our kinetic modeling suggests a causal link between dependence of inhibition on duration of glutamate exposure and effect on desensitization: models in which memantine increased occupancy of desensitized states also demonstrated greater inhibition of long than of synaptic-like glutamate applications. Because occupancy of desensitized states increases with duration of glutamate exposure, memantine's stabilization of desensitized states should lead to increased inhibition of responses activated by long glutamate applications or repetitive synaptic glutamate release. Our data also suggest that memantine specifically stabilizes a $\mathrm{Ca}^{2+}$-dependent desensitized state of GluN1/2A receptors. GluN1/2A receptors, but not GluN1/2B receptors, exhibit a $\mathrm{Ca}^{2+}$-dependent desensitized state (Traynelis et al., 2010), consistent with our finding that memantine slows recovery from desensitization of GluN1/2A, but not GluN1/2B receptors. Our ketamine results further support a link between dependence of inhibition on duration of glutamate exposure and the effects of NMDAR desensitization. Ketamine inhibits GluN1/2B (but not GluN1/2A) receptors more effectively during brief than long exposures to glutamate; ketamine also speeds recovery from GluN1/2B (but not GluN1/2A) receptor desensitization. The ketamine-induced reduction of desensitized state occupancy would be expected to decrease inhibition during long glutamate applications. Therefore, a channel blocker's effect on desensitization can predict whether and how inhibition will depend on the duration of glutamate exposure.

There are important structural implications of our findings. The conclusion that memantine and ketamine alter occupation specifically of desensitized states implies that binding of either blocker modifies the stability of desensitized relative to nondesensitized closed states. Therefore, the conformation of the blocker-binding site must differ between closed desensitized and closed non-desensitized states. Desensitization is modified by mutations in multiple receptor regions, including the NTD, ABD, ABD-M1 linker, TMD, and CTD (Krupp et al., 1998; Villarroel et al., 1998; Chen et al., 2004; Thomas et al., 2006a), supporting the idea that desensitization has broad effects on receptor conformation. Memantine and ketamine may serve as useful tools in furthering our understanding of the structural bases of NMDAR desensitization.

The sequence of molecular interactions involved in $\mathrm{Ca}^{2+}$ dependent desensitization is complex. $\mathrm{Ca}^{2+}$-dependent desensitization is partially mediated through calmodulin binding to the $\mathrm{C} 0$ region, and possibly the $\mathrm{C} 1$ region, of the GluN1 CTD, depending on the GluN1 splice variant (Ehlers et al., 1996; Krupp et al., 1999). If memantine's effect on desensitization also depends on GluN1 splice variant, then regulation of GluN1 splice variant expression could underlie possible brain-region- or cell-typespecific variations in memantine inhibition. Calcineurin also effects $\mathrm{Ca}^{2+}$-dependent desensitization (Tong and Jahr, 1994; Tong et al., 1995), has been shown to bind to the GluN2A CTD (Krupp et al., 2002), and may interact with calmodulin (Rycroft and Gibb, 2004). How NMDAR modulation by memantine, calmodulin, calcineurin, and other $\mathrm{Ca}^{2+}$ sensors may interact remains to be determined. Indeed, the complex interactions involved in
$\mathrm{Ca}^{2+}$-dependent desensitization may account for quantitative differences between our experimental measurement and model-based prediction (based on modeling $\mathrm{Ca}^{2+}$-dependent desensitization as a simple one-step process) of recovery from desensitization in memantine (Fig. 6D).

The ability of memantine to stabilize a $\mathrm{Ca}^{2+}$-dependent desensitized state of GluN1/2A receptors and of native synaptic NMDARs suggests a novel, rational mechanism of neuroprotection: preferential inhibition of NMDARs specifically in regions of neurons with excessive intracellular $\mathrm{Ca}^{2+}$ concentrations. Other NMDAR inhibitors also modulate desensitization, including ketamine (data presented here), the endogenous NMDAR modulator pregnanolone sulfate (Kussius et al., 2009), and membrane cholesterol (Korinek et al., 2015), suggesting that desensitization is modulated through multiple routes. Comparison of drug $\mathrm{IC}_{50}$ in high and low concentrations of extracellular $\mathrm{Ca}^{2+}$ could be used to screen new compounds for their ability to stabilize $\mathrm{Ca}^{2+}$ dependent desensitized states. Novel drugs that stabilize desensitized states powerfully could serve as highly selective agents for overactive NMDARs and thus exhibit improved neuroprotective characteristics.

More generally, the ability of ligands to stabilize specific receptor states may have broad relevance for drug development. A major challenge in the development of drugs to treat nervous system disorders is the identification of appropriate molecular drug targets (Pankevich et al., 2014). A potentially fruitful alternative strategy for drug development is to identify specific receptor states, rather than specific proteins, as drug targets.

\section{References}

Abdallah CG, Averill LA, Krystal JH (2015) Ketamine as a promising prototype for a new generation of rapid-acting antidepressants. Ann N Y Acad Sci 1344:66-77. CrossRef Medline

Ascher P, Nowak L (1988) The role of divalent cations in the N-methyl-Daspartate responses of mouse central neurones in culture. J Physiol 399: 247-266. CrossRef Medline

Auerbach A, Zhou Y (2005) Gating reaction mechanisms for NMDA receptor channels. J Neurosci 25:7914-7923. CrossRef Medline

Autry AE, Adachi M, Nosyreva E, Na ES, Los MF, Cheng PF, Kavalali ET, Monteggia LM (2011) NMDA receptor blockade at rest triggers rapid behavioural antidepressant responses. Nature 475:91-95. CrossRef Medline

Banke TG, Traynelis SF (2003) Activation of NR1/NR2B NMDA receptors. Nat Neurosci 6:144-152. CrossRef Medline

Beconi MG, Howland D, Park L, Lyons K, Giuliano J, Dominguez C, MunozSanjuan I, Pacifici R (2011) Pharmacokinetics of memantine in rats and mice. PLoS Curr 3:RRN1291.

Blanpied TA, Boeckman FA, Aizenman E, Johnson JW (1997) Trapping channel block of NMDA-activated responses by amantadine and memantine. J Neurophysiol 77:309-323. Medline

Blanpied TA, Clarke RJ, Johnson JW (2005) Amantadine inhibits NMDA receptors by accelerating channel closure during channel block. J Neurosci 25:3312-3322. CrossRef Medline

Chen HS, Lipton SA (1997) Mechanism of memantine block of NMDAactivated channels in rat retinal ganglion cells: uncompetitive antagonism. J Physiol 499:27-46. CrossRef Medline

Chen HS, Pellegrini JW, Aggarwal SK, Lei SZ, Warach S, Jensen FE, Lipton SA (1992) Open-channel block of N-methyl-D-aspartate (NMDA) responses by memantine: therapeutic advantage against NMDA receptormediated neurotoxicity. J Neurosci 12:4427-4436. Medline

Chen N, Ren J, Raymond LA, Murphy TH (2001) Changes in agonist concentration dependence that are a function of duration of exposure suggest $\mathrm{N}$-methyl-D-aspartate receptor nonsaturation during synaptic stimulation. Mol Pharmacol 59:212-219. Medline

Chen N, Li B, Murphy TH, Raymond LA (2004) Site within N-Methyl-Daspartate receptor pore modulates channel gating. Mol Pharmacol 65: 157-164. CrossRef Medline

Christie JM, Jahr CE (2009) Selective expression of ligand-gated ion chan- 
nels in L5 pyramidal cell axons. J Neurosci 29:11441-11450. CrossRef Medline

Clements JD, Westbrook GL (1991) Activation kinetics reveal the number of glutamate and glycine binding sites on the N-methyl-D-aspartate receptor. Neuron 7:605-613. CrossRef Medline

Clements JD, Lester RA, Tong G, Jahr CE, Westbrook GL (1992) The time course of glutamate in the synaptic cleft. Science 258:1498-1501. CrossRef Medline

Corazza O, Assi S, Schifano F (2013) From "Special K" to "Special M": the evolution of the recreational use of ketamine and methoxetamine. CNS Neurosci Ther 19:454-460. CrossRef Medline

Corlew R, Brasier DJ, Feldman DE, Philpot BD (2008) Presynaptic NMDA receptors: newly appreciated roles in cortical synaptic function and plasticity. Neuroscientist 14:609-625. CrossRef Medline

Dau A, Gladding CM, Sepers MD, Raymond LA (2014) Chronic blockade of extrasynaptic NMDA receptors ameliorates synaptic dysfunction and pro-death signaling in Huntington disease transgenic mice. Neurobiol Dis 62:533-542. CrossRef Medline

Dravid SM, Erreger K, Yuan H, Nicholson K, Le P, Lyuboslavsky P, Almonte A, Murray E, Mosely C, Barber J, French A, Balster R, Murray TF, Traynelis SF (2007) Subunit-specific mechanisms and proton sensitivity of NMDA receptor channel block. J Physiol 581:107-128. CrossRef Medline

Ehlers MD, Zhang S, Bernhadt JP, Huganir RL (1996) Inactivation of NMDA receptors by direct interaction of calmodulin with the NR1 subunit. Cell 84:745-755. CrossRef Medline

Emnett CM, Eisenman LN, Taylor AM, Izumi Y, Zorumski CF, Mennerick S (2013) Indistinguishable synaptic pharmacodynamics of the N-methyld-aspartate receptor channel blockers memantine and ketamine. Mol Pharmacol 84:935-947. CrossRef Medline

Erreger K, Dravid SM, Banke TG, Wyllie DJ, Traynelis SF (2005) Subunitspecific gating controls rat NR1/NR2A and NR1/NR2B NMDA channel kinetics and synaptic signalling profiles. J Physiol 563:345-358. CrossRef Medline

Fellin T, Pascual O, Gobbo S, Pozzan T, Haydon PG, Carmignoto G (2004) Neuronal synchrony mediated by astrocytic glutamate through activation of extrasynaptic NMDA receptors. Neuron 43:729-743. CrossRef Medline

Gideons ES, Kavalali ET, Monteggia LM (2014) Mechanisms underlying differential effectiveness of memantine and ketamine in rapid antidepressant responses. Proc Natl Acad Sci U S A 111:8649-8654. CrossRef Medline

Gilling KE, Jatzke C, Parsons CG (2007) Agonist concentration dependency of blocking kinetics but not equilibrium block of $\mathrm{N}$-methyl-d-aspartate receptors by memantine. Neuropharmacology 53:415-420. CrossRef Medline

Gilling KE, Jatzke C, Hechenberger M, Parsons CG (2009) Potency, voltagedependency, agonist concentration-dependency, blocking kinetics and partial untrapping of the uncompetitive N-methyl-D-aspartate (NMDA) channel blocker memantine at human NMDA (GluN1/GluN2A) receptors. Neuropharmacology 56:866-875. CrossRef Medline

Glasgow NG, Johnson JW (2014) Whole-cell patch-clamp analysis of recombinant NMDA receptor pharmacology using brief glutamate applications. Methods Mol Biol 1183:23-41. CrossRef Medline

Glasgow NG, Siegler Retchless B, Johnson JW (2015) Molecular bases of NMDA receptor subtype-dependent properties. J Physiol 593:83-95. CrossRef Medline

Gray JA, Shi Y, Usui H, During MJ, Sakimura K, Nicoll RA (2011) Distinct modes of AMPA receptor suppression at developing synapses by GluN2A and GluN2B: single-cell NMDA receptor subunit deletion in vivo. Neuron 71:1085-1101. CrossRef Medline

Groc L, Heine M, Cousins SL, Stephenson FA, Lounis B, Cognet L, Choquet D (2006) NMDA receptor surface mobility depends on NR2A-2B subunits. Proc Natl Acad Sci U S A 103:18769-18774. CrossRef Medline

Hansen KB, Ogden KK, Yuan H, Traynelis SF (2014) Distinct functional and pharmacological properties of triheteromeric GluN1/GluN2A/ GluN2B NMDA receptors. Neuron 81:1084-1096. CrossRef Medline

Hardingham GE, Bading H (2010) Synaptic versus extrasynaptic NMDA receptor signalling: implications for neurodegenerative disorders. Nat Rev Neurosci 11:682-696. CrossRef Medline

Harris AZ, Pettit DL (2007) Extrasynaptic and synaptic NMDA receptors form stable and uniform pools in rat hippocampal slices. J Physiol 584: 509-519. CrossRef Medline
Harris AZ, Pettit DL (2008) Recruiting extrasynaptic NMDA receptors augments synaptic signaling. J Neurophysiol 99:524-533. CrossRef Medline

Herman MA, Jahr CE (2007) Extracellular glutamate concentration in hippocampal slice. J Neurosci 27:9736-9741. CrossRef Medline

Hesselink MB, De Boer AG, Breimer DD, Danysz W (1999) Dopamine release in the prefrontal cortex in response to memantine following subchronic NMDA receptor blockade with memantine: a microdialysis study in rats. J Neural Transm 106:803-818. CrossRef Medline

Jahr CE (1992) High probability opening of NMDA receptor channels by L-glutamate. Science 255:470-472. CrossRef Medline

Johnson JW, Qian A (2002) Interaction between channel blockers and channel gating of NMDA receptors. Biol Membrany 19:17-22.

Johnson JW, Glasgow NG, Povysheva NV (2015) Recent insights into the mode of action of memantine and ketamine. Curr Opin Pharmacol 20: 54-63. CrossRef Medline

Kafi H, Salamzadeh J, Beladimoghadam N, Sistanizad M, Kouchek M (2014) Study of the neuroprotective effects of memantine in patients with mild to moderate ischemic stroke. Iran J Pharm Res 13:591-598. Medline

Kaufman AM, Milnerwood AJ, Sepers MD, Coquinco A, She K, Wang L, Lee H, Craig AM, Cynader M, Raymond LA (2012) Opposing roles of synaptic and extrasynaptic NMDA receptor signaling in cocultured striatal and cortical neurons. J Neurosci 32:3992-4003. CrossRef Medline

Kavalali ET, Monteggia LM (2015) How does ketamine elicit a rapid antidepressant response? Curr Opin Pharmacol 20:35-39. CrossRef Medline

Korinek M, Vyklicky V, Borovska J, Lichnerova K, Kaniakova M, Krausova B, Krusek J, Balik A, Smejkalova T, Horak M, Vyklicky L (2015) Cholesterol modulates open probability and desensitization of NMDA receptors. J Physiol 593:2279-2293. CrossRef Medline

Kotermanski SE, Johnson JW (2009) Mg2 + imparts NMDA receptor subtype selectivity to the Alzheimer's drug memantine. J Neurosci 29:27742779. CrossRef Medline

Kotermanski SE, Wood JT, Johnson JW (2009) Memantine binding to a superficial site on NMDA receptors contributes to partial trapping. J Physiol 587:4589-4604. CrossRef Medline

Kotermanski SE, Johnson JW, Thiels E (2013) Comparison of behavioral effects of the NMDA receptor channel blockers memantine and ketamine in rats. Pharmacol Biochem Behav 109:67-76. CrossRef Medline

Krupp JJ, Vissel B, Heinemann SF, Westbrook GL (1998) N-terminal domains in the NR2 subunit control desensitization of NMDA receptors. Neuron 20:317-327. CrossRef Medline

Krupp JJ, Vissel B, Thomas CG, Heinemann SF, Westbrook GL (1999) Interactions of calmodulin and alpha-actinin with the NR1 subunit modulate $\mathrm{Ca} 2+$-dependent inactivation of NMDA receptors. J Neurosci 19: 1165-1178. Medline

Krupp JJ, Vissel B, Thomas CG, Heinemann SF, Westbrook GL (2002) Calcineurin acts via the C-terminus of NR2A to modulate desensitization of NMDA receptors. Neuropharmacology 42:593-602. CrossRef Medline

Krystal JH, D’Souza DC, Mathalon D, Perry E, Belger A, Hoffman R (2003) NMDA receptor antagonist effects, cortical glutamatergic function, and schizophrenia: toward a paradigm shift in medication development. Psychopharmacology (Berl) 169:215-233. CrossRef Medline

Kussius CL, Kaur N, Popescu GK (2009) Pregnanolone sulfate promotes desensitization of activated NMDA receptors. J Neurosci 29:6819-6827. CrossRef Medline

Legendre P, Rosenmund C, Westbrook GL (1993) Inactivation of NMDA channels in cultured hippocampal neurons by intracellular calcium. J Neurosci 13:674-684. Medline

Le Meur K, Galante M, Angulo MC, Audinat E (2007) Tonic activation of NMDA receptors by ambient glutamate of non-synaptic origin in the rat hippocampus. J Physiol 580:373-383. CrossRef Medline

Léveillé F, El gaamouch F, Gouix E, Lecocq M, Lobner D, Nicole O, Buisson A (2008) Neuronal viability is controlled by a functional relation between synaptic and extrasynaptic NMDA receptors. FASEB J 22:4258-4271. CrossRef Medline

Lipton SA (2006) Paradigm shift in neuroprotection by NMDA receptor blockade: memantine and beyond. Nat Rev Drug Discov 5:160-170. CrossRef Medline

Lord B, Wintmolders C, Langlois X, Nguyen L, Lovenberg T, Bonaventure P (2013) Comparison of the ex vivo receptor occupancy profile of ketamine to several NMDA receptor antagonists in mouse hippocampus. Eur J Pharmacol 715:21-25. CrossRef Medline

Lu CW, Lin TY, Wang SJ (2010) Memantine depresses glutamate release 
through inhibition of voltage-dependent $\mathrm{Ca} 2+$ entry and protein kinase $\mathrm{C}$ in rat cerebral cortex nerve terminals: an NMDA receptor-independent mechanism. Neurochem Int 57:168-176. CrossRef Medline

Maki BA, Popescu GK (2014) Extracellular $\mathrm{Ca}(2+)$ ions reduce NMDA receptor conductance and gating. J Gen Physiol 144:379-392. CrossRef Medline

Maskell PD, Speder P, Newberry NR, Bermudez I (2003) Inhibition of human alpha 7 nicotinic acetylcholine receptors by open-channel blockers of N-methyl-D-aspartate receptors. Br J Pharmacol 140:1313-1319. CrossRef Medline

Mealing GA, Lanthorn TH, Murray CL, Small DL, Morley P (1999) Differences in degree of trapping of low-affinity uncompetitive N-methyl-Daspartic acid receptor antagonists with similar kinetics of block. J Pharmacol Exp Ther 288:204-210. Medline

Miller OH, Yang L, Wang CC, Hargroder EA, Zhang Y, Delpire E, Hall BJ (2014) GluN2B-containing NMDA receptors regulate depression-like behavior and are critical for the rapid antidepressant actions of ketamine. eLife 3:e03581. CrossRef Medline

Milnerwood AJ, Gladding CM, Pouladi MA, Kaufman AM, Hines RM, Boyd JD, Ko RW, Vasuta OC, Graham RK, Hayden MR, Murphy TH, Raymond LA (2010) Early increase in extrasynaptic NMDA receptor signaling and expression contributes to phenotype onset in Huntington's disease mice. Neuron 65:178-190. CrossRef Medline

Nosyreva E, Szabla K, Autry AE, Ryazanov AG, Monteggia LM, Kavalali ET (2013) Acute suppression of spontaneous neurotransmission drives synaptic potentiation. J Neurosci 33:6990-7002. CrossRef Medline

Okamoto S, Pouladi MA, Talantova M, Yao D, Xia P, Ehrnhoefer DE, Zaidi R, Clemente A, Kaul M, Graham RK, Zhang D, Vincent Chen HS, Tong G, Hayden MR, Lipton SA (2009) Balance between synaptic versus extrasynaptic NMDA receptor activity influences inclusions and neurotoxicity of mutant huntingtin. Nat Med 15:1407-1413. CrossRef Medline

Pankevich DE, Altevogt BM, Dunlop J, Gage FH, Hyman SE (2014) Improving and accelerating drug development for nervous system disorders. Neuron 84:546-553. CrossRef Medline

Paoletti P, Ascher P, Neyton J (1997) High-affinity zinc inhibition of NMDA NR1-NR2A receptors. J Neurosci 17:5711-5725. Medline

Paoletti P, Bellone C, Zhou Q (2013) NMDA receptor subunit diversity: impact on receptor properties, synaptic plasticity and disease. Nat Rev Neurosci 14:383-400. CrossRef Medline

Papouin T, Ladépêche L, Ruel J, Sacchi S, Labasque M, Hanini M, Groc L, Pollegioni L, Mothet JP, Oliet SH (2012) Synaptic and extrasynaptic NMDA receptors are gated by different endogenous coagonists. Cell 150: 633-646. CrossRef Medline

Papp E, Rivera C, Kaila K, Freund TF (2008) Relationship between neuronal vulnerability and potassium-chloride cotransporter 2 immunoreactivity in hippocampus following transient forebrain ischemia. Neuroscience 154:677-689. CrossRef Medline

Parsons CG, Stöffler A, Danysz W (2007) Memantine: a NMDA receptor antagonist that improves memory by restoration of homeostasis in the glutamatergic system: too little activation is bad, too much is even worse. Neuropharmacology 53:699-723. CrossRef Medline

Parsons MP, Raymond LA (2014) Extrasynaptic NMDA receptor involvement in central nervous system disorders. Neuron 82:279-293. CrossRef Medline

Persson J (2013) Ketamine in pain management. CNS Neurosci Ther 19: 396-402. CrossRef Medline

Petralia RS, Wang YX, Hua F, Yi Z, Zhou A, Ge L, Stephenson FA, Wenthold RJ (2010) Organization of NMDA receptors at extrasynaptic locations. Neuroscience 167:68-87. CrossRef Medline

Povysheva NV, Johnson JW (2012) Tonic NMDA receptor-mediated current in prefrontal cortical pyramidal cells and fast-spiking interneurons. J Neurophysiol 107:2232-2243. CrossRef Medline

Povysheva NV, Johnson JW (2016) Effects of memantine on the excitationinhibition balance in prefrontal cortex. Neurobiol Dis 96:75-83. CrossRef Medline

Riebe I, Seth H, Culley G, Dósa Z, Radi S, Strand K, Fröjd V, Hanse E (2016) Tonically active NMDA receptors: a signalling mechanism critical for interneuronal excitability in the CA1 stratum radiatum. Eur J Neurosci 43:169-178. CrossRef Medline
Rosenmund C, Westbrook GL (1993) Rundown of N-methyl-D-aspartate channels during whole-cell recording in rat hippocampal neurons: role of Ca2 + and ATP. J Physiol 470:705-729. CrossRef Medline

Rycroft BK, Gibb AJ (2004) Inhibitory interactions of calcineurin (phosphatase $2 \mathrm{~B}$ ) and calmodulin on rat hippocampal NMDA receptors. Neuropharmacology 47:505-514. CrossRef Medline

Schorge S, Elenes S, Colquhoun D (2005) Maximum likelihood fitting of single channel NMDA activity with a mechanism composed of independent dimers of subunits. J Physiol 569:395-418. CrossRef Medline

Sobolevsky AI, Koshelev SG, Khodorov BI (1998) Interaction of memantine and amantadine with agonist-unbound NMDA-receptor channels in acutely isolated rat hippocampal neurons. J Physiol 512:47-60. CrossRef Medline

Stroebel D, Carvalho S, Grand T, Zhu S, Paoletti P (2014) Controlling NMDA receptor subunit composition using ectopic retention signals. J Neurosci 34:16630-16636. CrossRef Medline

Thomas CG, Krupp JJ, Bagley EE, Bauzon R, Heinemann SF, Vissel B, Westbrook GL (2006a) Probing N-methyl-D-aspartate receptor desensitization with the substituted-cysteine accessibility method. Mol Pharmacol 69:1296-1303. CrossRef Medline

Thomas CG, Miller AJ, Westbrook GL (2006b) Synaptic and extrasynaptic NMDA receptor NR2 subunits in cultured hippocampal neurons. J Neurophysiol 95:1727-1734. CrossRef Medline

Tong G, Jahr CE (1994) Regulation of glycine-insensitive desensitization of the NMDA receptor in outside-out patches. J Neurophysiol 72:754-761. Medline

Tong G, Shepherd D, Jahr CE (1995) Synaptic desensitization of NMDA receptors by calcineurin. Science 267:1510-1512. CrossRef Medline

Tovar KR, Westbrook GL (1999) The incorporation of NMDA receptors with a distinct subunit composition at nascent hippocampal synapses in vitro. J Neurosci 19:4180-4188. Medline

Tovar KR, McGinley MJ, Westbrook GL (2013) Triheteromeric NMDA receptors at hippocampal synapses. J Neurosci 33:9150-9160. CrossRef Medline

Traynelis SF, Wollmuth LP, McBain CJ, Menniti FS, Vance KM, Ogden KK, Hansen KB, Yuan H, Myers SJ, Dingledine R (2010) Glutamate receptor ion channels: structure, regulation, and function. Pharmacol Rev 62:405496. CrossRef Medline

Villarroel A, Regalado MP, Lerma J (1998) Glycine-independent NMDA receptor desensitization: localization of structural determinants. Neuron 20:329-339. CrossRef Medline

Wild AR, Akyol E, Brothwell SL, Kimkool P, Skepper JN, Gibb AJ, Jones S (2013) Memantine block depends on agonist presentation at the NMDA receptor in substantia nigra pars compacta dopamine neurones. Neuropharmacology 73:138-146. CrossRef Medline

Wroge CM, Hogins J, Eisenman L, Mennerick S (2012) Synaptic NMDA receptors mediate hypoxic excitotoxic death. J Neurosci 32:6732-6742. CrossRef Medline

Wu YN, Johnson SW (2015) Memantine selectively blocks extrasynaptic NMDA receptors in rat substantia nigra dopamine neurons. Brain Res 1603:1-7. CrossRef Medline

Xia P, Chen HS, Zhang D, Lipton SA (2010) Memantine preferentially blocks extrasynaptic over synaptic NMDA receptor currents in hippocampal autapses. J Neurosci 30:11246-11250. CrossRef Medline

Zanos P, Moaddel R, Morris PJ, Georgiou P, Fischell J, Elmer GI, Alkondon M, Yuan P, Pribut HJ, Singh NS, Dossou KS, Fang Y, Huang XP, Mayo CL, Wainer IW, Albuquerque EX, Thompson SM, Thomas CJ, Zarate CA Jr, Gould TD (2016) NMDAR inhibition-independent antidepressant actions of ketamine metabolites. Nature 533:481-486. CrossRef Medline

Zhao X, Marszalec W, Toth PT, Huang J, Yeh JZ, Narahashi T (2006) In vitro galantamine-memantine co-application: mechanism of beneficial action. Neuropharmacology 51:1181-1191. CrossRef Medline

Zhou X, Ding Q, Chen Z, Yun H, Wang H (2013a) Involvement of the GluN2A and GluN2B subunits in synaptic and extrasynaptic N-methyl$\mathrm{D}$-aspartate receptor function and neuronal excitotoxicity. J Biol Chem 288:24151-24159. CrossRef Medline

Zhou X, Hollern D, Liao J, Andrechek E, Wang H (2013b) NMDA receptormediated excitotoxicity depends on the coactivation of synaptic and extrasynaptic receptors. Cell Death Dis 4:e560. CrossRef Medline 